\title{
THE PLURISERIAL RIBEIRA MAGMATIC SYSTEM 590, SE / S BRAZIL AND URUGUAY*
}

\author{
EBERHARD WERNICK
}

\begin{abstract}
The Pluriserial Ribeira Magmatic System-590 (PRMS-590) which acted in the Late Precambrian Ribeira Belt in SE/S Brazil, and Uruguay about $580-610 \mathrm{Ma}$ ago, is described and discussed. The system, developed during the Post-Collisional Mentation \& Uplift evolutional stage of the Ribeira Belt, comprises mainly six groups (series) of high-K rocks: (1) alkali-calcic Caledonian I-type metaluminous (quartz) monzonites \& syenites and monzo-, syeno- \& alkali-feldspar granites; (2) alkali-calcic metaluminous (quartz) monzonites \& syenites and monzo-, syeno- \& alkali-feldspar rapakivi granites; (3) shoshonitic metaluminous \pm fayalite \pm pyroxene \pm hornblende \pm biotite (quartz) monzonites \& syenites and monzo-, syeno-\& alkali-feldspar granites sometimes with rare late crystallised mafic soda minerals; (4) peralkaline mafic soda minerals bearing (quartz) monzonites \& syenites and monzo-, syeno- \& alkali-feldspar granites with or without \pm fayalite \pm pyroxene \pm hornblende \pm biotite; (5) K-alkaline metaluminous suites of \pm (quartz) gabbros \& monzogabbros \pm (quartz) monzodiorites \& diorites \pm (quartz) monzonites \& syenites and granites and (6) ultrapotassic under- and oversaturated monzonites \& syenites with variable amounts of orthopyroxene. These rocks are either of lower crustal $(1,2$, and possibly 3$)$ or mantelic origin $(4,5,6)$, a fact which indicates the simultaneous melting of lower crust and secondary enriched mantle during that time. Several tectonic, geochemical and isotopic aspects are presented to show the internal coherence of the PRMS-590.
\end{abstract}

Keywords: Ribeira Fold Belt, Brasiliano Cycle (Late Precambrian), Magmatic System, SE/S Brazil, and Uruguay, High-K rocks

INTRODUCTION A Magmatic System is here defined as "the sum of all magmatic phenomena occurred in a considered time span as the result of a geodynamic process which represents a certain stage in the evolution of the lithosphere characterised by particular compositional, pressure, temperature, Theological, etc. conditions. By this a magmatic system must show an internal overall coherence characterised by a harmoniously integrated and mutual complementary interplay of tectonic, magmatogenic, magmatic evolutional and mineralising processes over large areas".

The aim of this paper is to offer a description and an integrated interpretation of some aspects of the Pluriserial Ribeira Magmatic System-590 (PRMS-590) developed in the Late Precambrian Ribeira Belt in SE/S Brazil and Uruguay about 580-610 Ma ago. This system was up to now only briefly outlined and constrained by Wernick (1998a,b).

THE RIBEIRA BELT 1. The Ribeira (or Atlantic, Parafba, Parafba do Sul and Coastal) Belt runs parallel to the South American coast with an overall NE-SW direction for about $2600 \mathrm{~km}$ and variable width from near the city of Vitoria (State of Espírito Santo, SE Brazil) to southern Uruguay (Fig. 1). Northern of Vitoria the strike of the belt changes and it is named Araçuaí Belt for not completely clarified reasons (Fig. 2).

2. The Ribeira Belt displays dominantly transpressive tectonic features (Harland 1971, Sanderson \& Marchini 1984, Soper \& Hutton 1984, Strachan et al. 1992, Sengor 1990, Fossen \& Tikoff 1993, Brown 1994,Ebert et al. 1996,Machado 1997) including an expressive bundle of NE-SW thrust and mainly dextral shear zones (wrench faults) currently called the Parafba Belt (PSB) or Atlantic Thrust \& Shear Belt (ATSB). However, the tectonic evolution of the Ribeira Belt comprises three phases, partly overlapping in time. The first (and oldest) is essentially a thrust phase in a transpressive regime with press- much larger/larger than the trans-component resulting in oblate $(\mathrm{K}<1)$ Flinn deformation ellipsoids (Ferreira 1997, Ferreira \& Wernick 1997). The second is mainly a transcurrent phase developed in a transcurrent (with trans larger/equal than the press-component) to transtensional or transtractive (with trans equal/minor than the tensional-componeni) stress regime resulting in prolate $(K>1)$ Flinn deformation ellipsoids (Ferreira 1997, Ferreira \& Wernick 1997). The third (and youngest) phase is dominated by normal faults developed in a tensional regime.

3. The final evolutional stage of the Ribeira Belt is characterised by a change of the stress vector $\tau_{1}$ from about $\mathrm{E}$ to nearly $\mathrm{N}$. This allows to explain some features of the youngest regional and often transverse folding phase which affect larger parts of the Ribeira Belt with the development of an "egg-box" (domes and basins) structure. In this way, Soares et al. (1990), postulated for the change from late syn- to the post-orogenic evolutional stage of the belt a counterclockwise rotation of the main stress vector which implies in a regional change from dextral to sinistral fault movement as well as the reactivation of previously more and less stabilised areas. More or less similar propo- sitions are from Machado \& Endo (1993), Endo \& Machado (1993, 1995), and Machado (1997), among several other authors.

4. Beside the dominant NE-SW transcurrent/transtensional fault system also a somewhat younger and less expressive about E-W dextral transcurrent/transtensional fault system occurs in the ATSB (Wernick et al. 1981) bending the regional NE-SW metamorphic foliation with

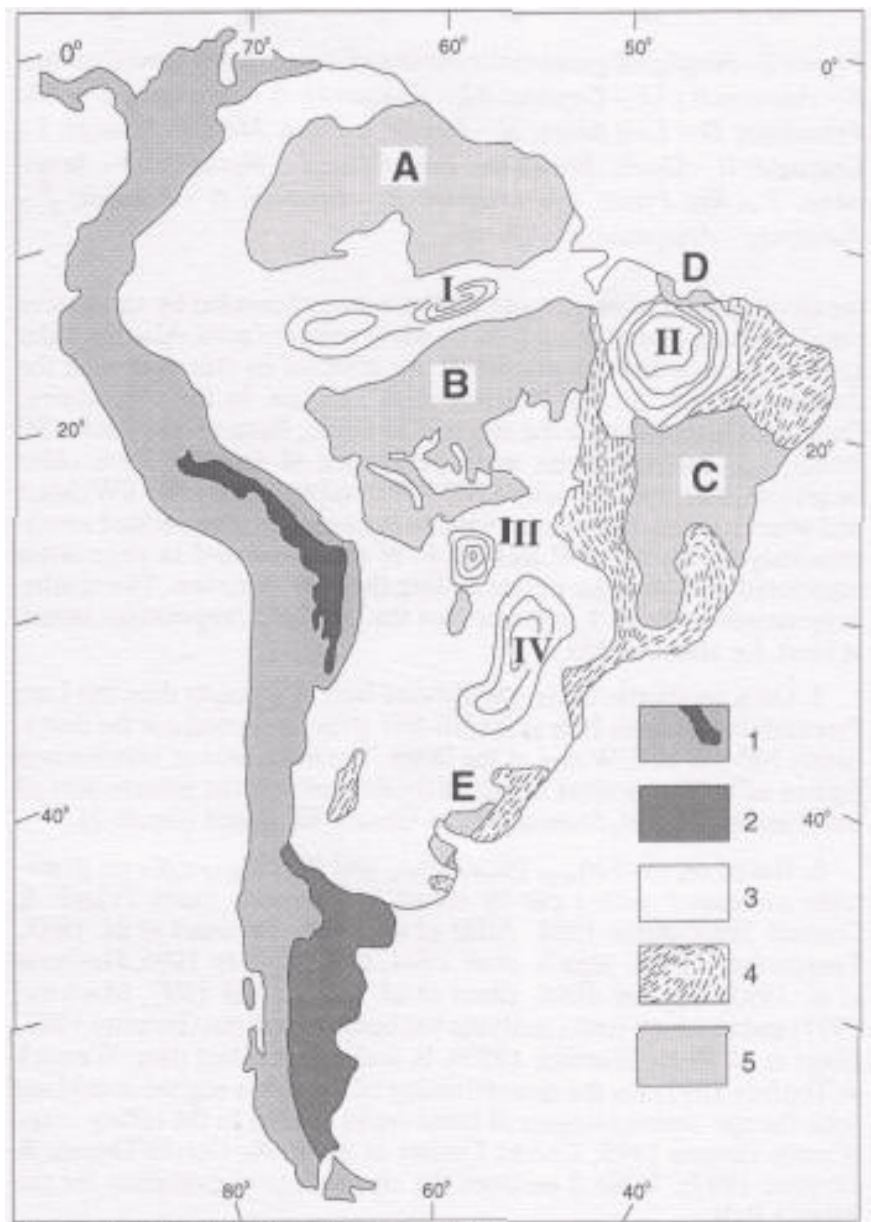

Figure 1 - Simplified geotectonic outline of South America. 1 -Andean Foldbelt; 2 - Patagonian Platform with Paleozoic basement; 3-5 South American Platform with Late Precambrian foldbelts (3) Cratons (4) and Phanerozoic sediments (5). Cratons: Guyana (A), Guapore (B), São do Francisco (C), São Luis (D). Phanerozoic basins with depocentri: Amazonas (1), Maranhão (II), Alto Xingu (III), Paraná (IV). 


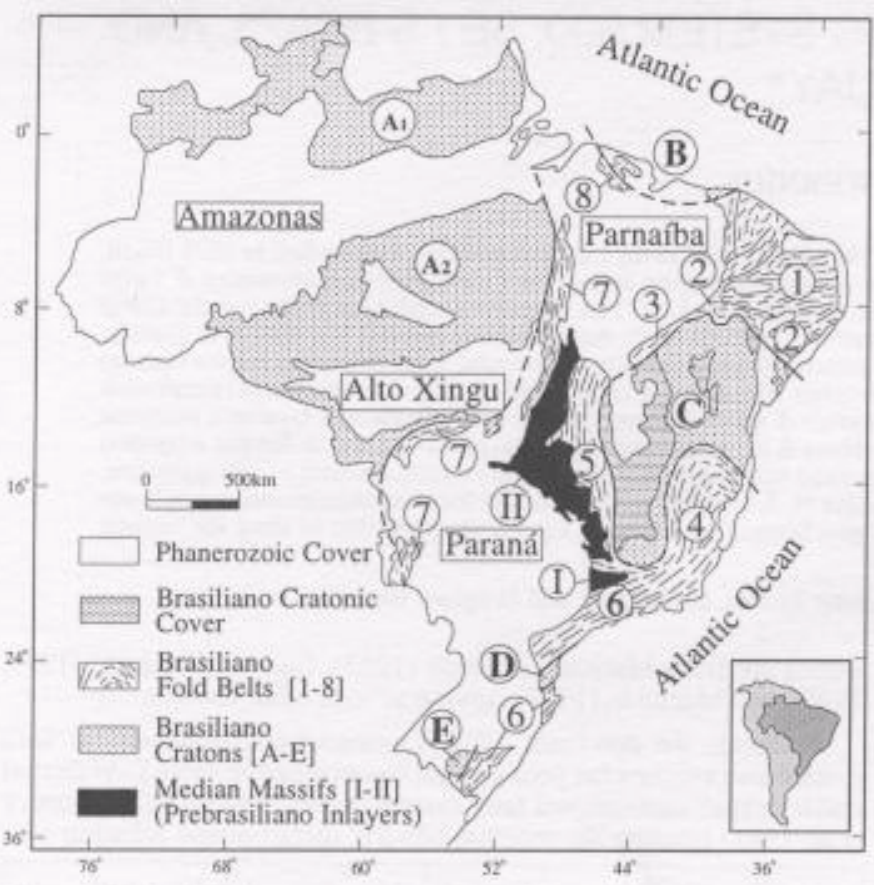

Figure 2 - Simplified geotectonic outline of Brazil. Brasiliano Cratons: A - Amazonas (Al - Guyana, A2 - Guaporé); B - São Luis; C - Sao Francisco; D - Luis Alves; E - Rio de la Plata. Median Massifs: I Guaxupe; II - Golds. Brasiliano Fold Belts: I - Nordeste; 2 - Sergipano; 3 - Rio Preto; 4 - Araçuai; 5 - Brasília; 6 - Ribeira; 7 Paraguay - Araguaia; 8 - Gurupi.

the development of megasigmoidal structures bounded by successive parallel to subparallel about E-W trending wrench faults. Also the older synconvergence Ribeira granitoids are affected by this drag with the development of "S" and "hockey stick" shapes. In the polydiapiric Cantareira batholith near the city of São Paulo, State of São Paulo, SE Brazil, age determinations were performed in samples from older facies (magmatic pulses) with a NE-SW trend and cut by NE-S W thrust and wrench faults; from facies which emplacement is controlled simultaneously by the NE-SW and the E-W directions and in pegmatites associated with younger pulses cutting the E-W direction. The results, summarised in Table 1, indicate that the granitoid magmatism lasted, at least, for about $64 \mathrm{Ma}$.

5. On a geometric basis, the Ribeira Belt is younger than the Late Precambrian Brasília Belt as its NE-SW structural trend cut the dominantly NE-SW to E-W one of the latter. The main area of interference figures of both structural trends is located around the eastern part of the Guaxupe Massif, State of Minas Gerais, SE Brazil (figure 2).

6. Based on $(\mathrm{Sr} / \mathrm{Rb})_{\mathrm{WR}},(\mathrm{Sm} / \mathrm{Nd})_{\mathrm{WR}}$ and $(\mathrm{U} / \mathrm{Pb})_{\mathrm{ZM}}$ ages on granitoids associated with / cut by thrust and wrench faults (Vlach \& Cordani 1986, Artur 1988, Artur et al. 1988, Tassinari et al. 1988, Teuppenhayn 1994, Siga Jr. Et al. 1994, 1997, Siga Jr. 1995, Heilbron et al. 1995, Topfner 1996, Ebert et al. 1996, Kaul 1997, Machado 1997) and in which strain analyses has been carried out (Ferreira 1997, Ebert et al. 1996, Wernick 1997a, b, and unpublished data, Wernick \& Topfner 1997) for the determination of the stress regime combined with the age determinations of basic rocks related to the rifting stage (Correa-Gomes 1995, Correa Gomes et al. 1996, Correa-Gomes \& Oliveira 1997). Table 2 outlines the chronological evolution for the Ribeira Belt.

7. The regional structure of the Ribeira Belt in the States of São Paulo, Minas Gerais, Rio de Janeiro and Espírito Santo is a tectonic fan representing a positive regional megaflower which NE-SW axis is centred in the Paraíba do Sul valley (Machado \& Endo 1993, Ebert et al. 1996, Machado et al. 1996). In this region the foliation of the rocks is (sub) vertical due to the expressive Paraíba do Sul shear zone combined with the development (in the State of Rio de Janeiro) of the Paraíba do Sul megasynform and, more to the SE, the Rio de Janeiro mega-antiform (Heilbron et al. 1995). From this central part of the belt allochtonous Pre-Brasiliano basement, Pre-Brasiliano basement + Brasiliano cover or Brasiliano cover comprising tectonic thrust slices
Table 1 - Ages, tectonic phases and emplacement episodes for the Cantareira batholith in the Ribeira Belt, State of São Paulo, SE Brazil, after Wernick \& Teuppenhayn, 1999, modified.

\section{3. - YOUNGER PHASE}

Regional tensional faulting.

Emplacement of the Taipas granite (an eastern Cantareira satellite) and its associated pegmatitic Penis tourmaline granite cutting the E-W trend.

Age of the Perus layered tourmaline granite (Teuppenhayn, 1994): $(\mathrm{U} / \mathrm{Pb})_{\mathrm{M}}: 566 \pm 6 \mathrm{Ma}$

\section{2. - TRANSITIONAL PHASE}

Development of the subsidiary E-W structural direction. Drag of the older NE-SW structures and development of the E-W wrench fault system.

Emplacement of younger facies in the Cantareira granite controlled by the E-W direction.

Age of the syn-E-W porphyritic Canivete facies in the Cantareira granite (Teuppenhayn, 1994): $(\mathrm{U} / \mathrm{Pb})_{7}, 572 \pm 9 \mathrm{Ma}$.

\section{1. - EARLY PHASE}

Development of the main NE-SW structural direction comprising fold axes, metamorphic foliation, thrust and transcurrent faults systems.

Emplacement of the main Cantareira granite facies with NE-SW elongation and cut by NESW thrust and wrench faults.

Age of the syn-NE-SW megaporphyritic Pirituba facies in the Cantareira granite (Topfner, 1996).: (U/Pb)/::630 $\pm 8 \mathrm{Ma}$.

$\underline{\mathrm{VI}}=$ Monazite $\mathrm{Z}=$ Zircon

Table 2 - Temporal evolution of the Ribeira Belt, after Wernick, 1997a, $b$ and Wernick \& Topfner, 1997, modified.

5. POST (E-W) WRENCH FAULTING MAGMATISM (EMPLACEMENT IN A TENSIONAL STRESS REGIME

Final magmatism

4. K-RICH ROCKS FROM THE PLURISERIAL RIBEIRA MAGMATIC SYSTEM-590 (615-575 Ma.) (POSTCOLUSIONAL MENTATION \& UPLIFT STAGE). TRANSCURRENT TO TENSIONAL

I-Caledonian-type

(Morungaha magmatism)

Rapakivi-type

(Cahreuva magmatis

(Serra do Mar magmatism)

Peralka line-type

(Shra do Mar magmatism)

(Piracaia magmatism)

Ultrapotassic-type

(Pedra Branca magmatism)

590-589 Ma.

$585 \mathrm{Ma}$

615-580 Ma.

$595-580 \mathrm{Ma}$

600 Ma.

615 - 610 Ma.

3. E-W WRENCH FAULTING (WSTCOUJSIONAL MENTATION* UPIJFT STAGE)

3.2. Transtractive stress regine plcice

$590-580 \mathrm{Ma}$

Call-alkaline to alkali-calcic, often high-K,

1. Transcurrent stress regime phase

(Calc-alkaline, often high-K, Cordilleran I-type magmatism)

625-595 Ma.

2. THRUST FAULTING TOWARDS NVV AND NE/SVV WRENCH FAULTING ( SUBDUCTIONSTAGE)

2.1. Transpressive + transcurrent stress regime phases

(Calc-alkaline, often high-K, CordiUeran I-type mag

(Calc-alkaline, often high-K, CordiUcran l-type magmatism)
Determined between

Possible since

1. RIFFTINC STAGE

I.I. Initial plume head mafic magmatism

1000 - $950 \mathrm{Ma}$

with successively lower dips are interstacked either to NW (in the direction of the São Francisco craton where autochtonous Brasiliano covers lay on a Pre-Brasiliano basement) or to SE (in the direction of the eastern South-American or western African Atlantic coast) (Fig. 3).

The nappes were assembled from the central zone to the São Francisco craton in the States of São Paulo and Minas Gerais in an internal, middle and external thrust zone (Campos Neto \& Basei 1983a, b, Campos Neto \& Figueiredo 1995, Campos Neto et al. 1990) and in the States of Rio de Janeiro and Minas Gerais in a NW upper-, middleand lower-allochtonous thrust zone, the latter resting on autochtonous 
Table 3 - Tectonic domains of the Ribeira Belt in the States of São Paulo and Rio de Janeiro after several authors from NW (Craton São Francisco) to SE (Atlantic coast). The limits of the domains are important low-or high-angle shear zones. Horizontal lines are not necessarily equivalent geographic or tectonic boundaries.

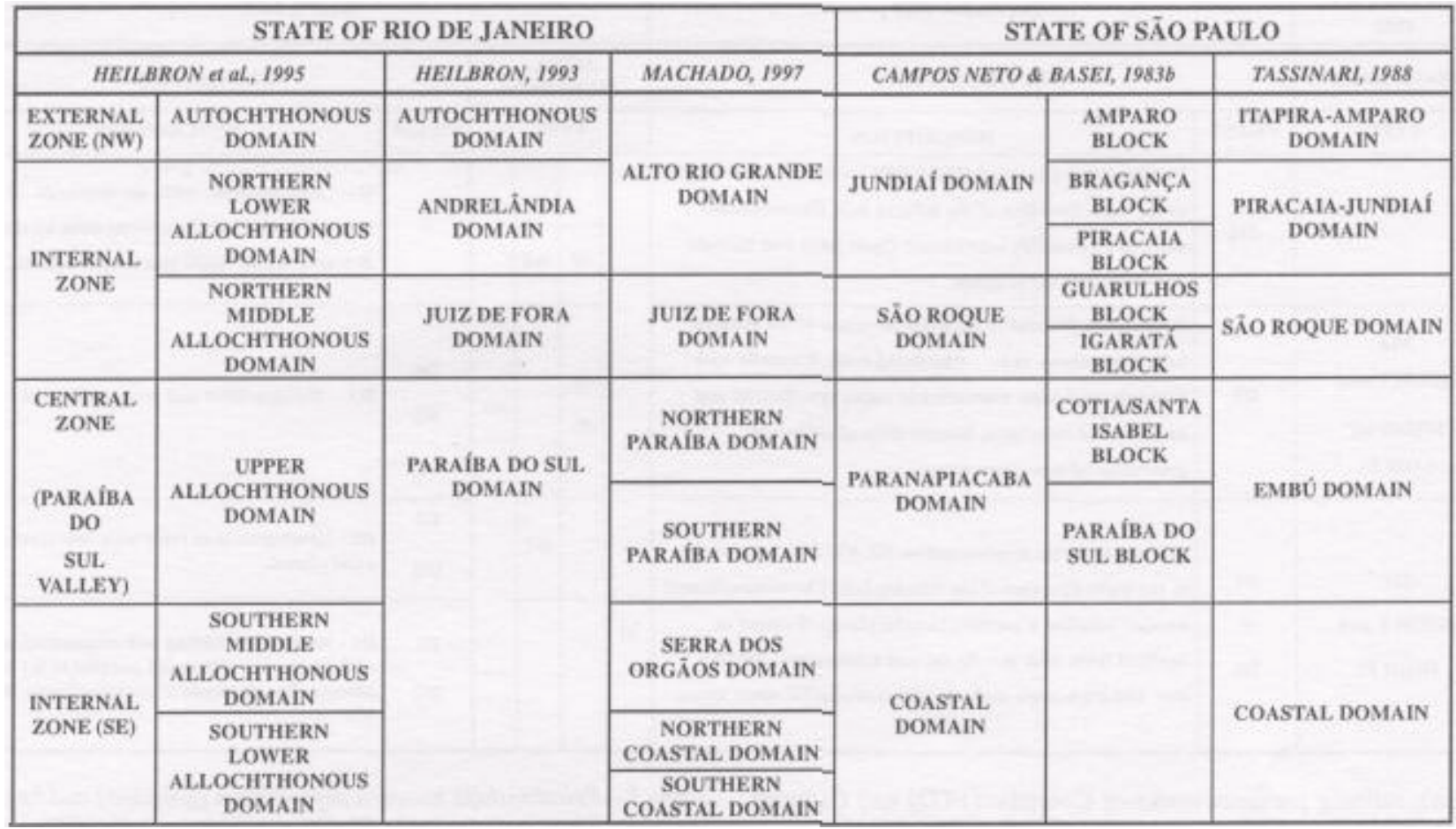

Brasiliano sediment covering the São Francisco craton (Heilbron et al. 1995). The SE limb of the tectonic fan is only partially preserved in Brazil. In the State of Rio de Janeiro Heilbron et al. (1995), recognised its middle- and lower-allochtonous thrust zone but not the autochtonous forland that must be seek in eastern Africa.

The several thrust slices or part of them (if they are clearly subdivided by later expressive dextral strike-slip faults) are called "domains". Unfortunately their names changed for a same author in a same area with time, from author to author in a same area and from author to author in neighbouring areas (Table 3). This aspect made regional syntheses a hard task as also the limits of each domain change for a same author through time.

8. For many authors the evolution of the Ribeira Belt comprises two phases of regional metamorphism and 3 or 4 main folding phases associated or not with the development of new or the reactivation of older expressive thrust \& wrench faults and the emplacement of successive generations of granitoids. Table 4 shows Heilbron's et al. (1995) and Machado's (1997) metamorphic, deformational and magmatic evolutional scheme for the Ribeira belt in the States of Rio de Janeiro and Minas Gerais, but it must be stressed that Machado's (1997) strain model, here chosen for its easy overall glance, is a simplification of a much more detailed one presented by Heilbron et al. (1995) in their figure 2 for different domains in the States of Rio de Janeiro and Minas Gerais. However, both schemes do not differ significantly from that proposed by Hasui (1975), for the Paranapiacaba Domain, State of São Paulo.

The metamorphism Ml and M2 in Table 4, according to Heilbron et al. (1995), have about the same temperature but quite different pressure regimes. For Heilbron et al. (1995), Ml is of medium/high pressure $(8-10 \mathrm{~kb})$ and high temperature $\left(700-800^{\circ} \mathrm{C}\right)$ peaking during D2 and expressed in S1 and S2, also with the development of banded migmatites. The regional metamorphism Ml decreases from the Paraíba do Sul valley either to the NW or to SE. In the NW limb of the regional structural fan Heilbron et al. (1995), characterised the following successive critical metamorphic parageneses or minerals: K-feldspar + sillimanite $\rightarrow$ kyanite $\rightarrow$ garnet $\rightarrow$ biotite. M2 is of low/medium pressure, peaking during D3 and affecting S2. This metamorphism promotes an intensive melting of Pre-Brasiliano and Brasiliano rocks with the production of migmatites and S-type granites, together with the development of cordierite in metapelitic rocks. The temporal sequence $\mathrm{Ml} \rightarrow \mathrm{M} 2$, preserved in some S2 plurifacial rocks, charac-

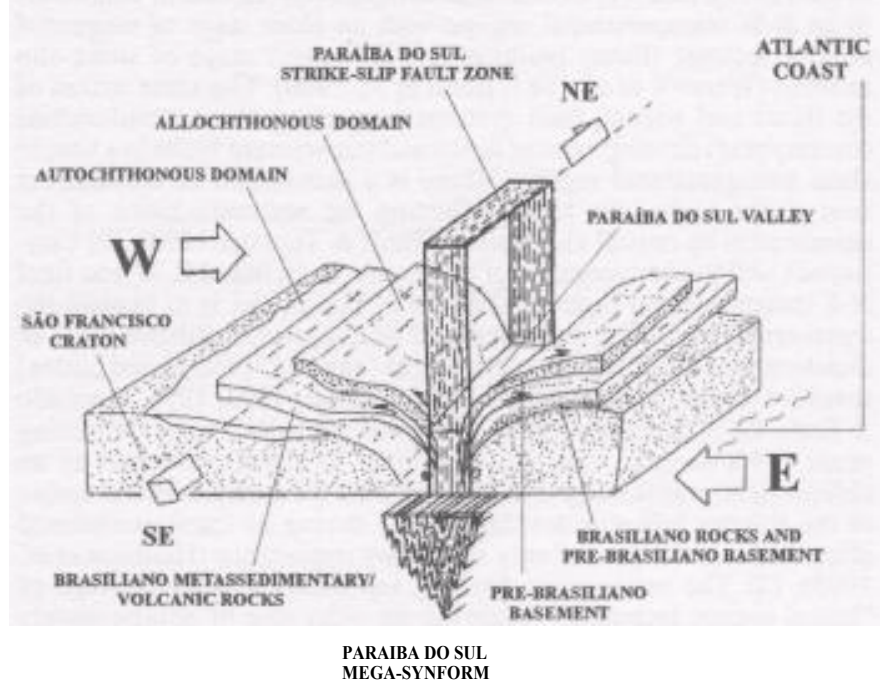

Figure 3 - Sketch of the structural organisation of the Ribeira Belt in the State of Rio de Janeiro, SE Brazil.

terises an isothermal decompressional metamorphic regime (Harley 1989). However, for other authors (e.g. Ribeiro et al. 1995) this plurifacial rocks only occur in the interference area between the Brasilia and Ribeira belts, and $\mathrm{Ml}$ is referred to the former and $\mathrm{M} 2$ to the latter.

Neither Heilbron et al. (1995), nor Machado (1997), characterised the thermal metamorphism of the huge batholiths emplaced during D2 and D3 but this process is well described by Coutinho (1972), Hasui (1975), Carneiro (1983) and Dantas (1990), among several others, in the Sao Roque Domain, State of Sao Paulo, where wide contact aureoles disturb significantly the isotherms related to the regional metamorphism. In this domain, Dantas (1990) analysed the relationships between deformation (foliation) and heat flux (porphyroblast 
Table 4 - Metamorphic events (M, $m, M, m)$ and folding (D) \& faulting (D) phases of the Ribeira Belt in the States of Rio de Janeiro and São Paulo (Paranapiacaba domain). Metamorphism: $M=$ regional; $M=$ retrograde; $m=$ contact; $m=$ dynamic (cataclastic). $m$ is related with $D$.

\begin{tabular}{|c|c|c|c|c|c|c|c|c|}
\hline $\begin{array}{l}\text { HEILBRON et al., } \\
1995\end{array}$ & & MACHADO, 1997 & . & & & & & HASUI, 1975 \\
\hline METAMORPHISM & & DEFORMATION & & $\begin{array}{l}\text { MET } \\
\text { OORPI }\end{array}$ & $\begin{array}{l}\text { TA. } \\
\text { HISM }\end{array}$ & & & DEFORMATION \\
\hline TYPE & PHASE & DESCRIPTION & & TYP & & & PHASE & DESCRIPTION \\
\hline & D4 & $\begin{array}{l}\text { Dominantly transversal (NNW-SSE, NW-SE, WNW-ESE) } \\
\text { to the main direction of the Ribeira belt. Discontinuous } \\
\text { structures, partially extensional. Open folds and discrete } \\
\text { ductile/ruptile shear zones. }\end{array}$ & & $M$ & $\mathbf{m} 2$ & & $D$ & $\begin{array}{l}\text { D- Lineagenesis with development of } \\
\text { expressive tectonic lineaments done by thrust } \\
\text { \& transcurrent faults and deep fractures. }\end{array}$ \\
\hline $\begin{array}{l}\text { M2 } \\
\text { (HIGH T and } \\
\text { MEDIUM/ } \\
\text { LOW P) }\end{array}$ & D3 & $\begin{array}{l}\text { Dominantly parallel to the main direction of the Ribeira } \\
\text { belt. Open (Syn - M2 .) to closed folds, normally with } \\
\text { subhorizontal axes, assembled in major synclinorial and } \\
\text { anticlinorial structures. Reactivation of older and } \\
\text { generation of new shear zones. }\end{array}$ & & $\begin{array}{l}M \\
\text { (?) }\end{array}$ & & $m I$ & $\begin{array}{l}\text { D3 } \\
\text { (D) }\end{array}$ & D3 - Transposition and crenulation of S2. \\
\hline M1 & D1 & $\begin{array}{l}\text { Synmetamorphic-migmatization. NE-SW foliation parallel } \\
\text { to the main direction of the Ribeira belt. The compositional }\end{array}$ & & & m1 & & $\begin{array}{l}\text { D2 } \\
\text { (D) }\end{array}$ & $\begin{array}{l}\text { D2 - Development of folds with sub-vertical } \\
\text { axial planes. }\end{array}$ \\
\hline $\begin{array}{c}\text { (HIGH T and } \\
\text { HIGH P) }\end{array}$ & $\begin{array}{l}+ \\
\text { D2 }\end{array}$ & $\begin{array}{l}\text { banded foliation is parallel to axial planes of closed to } \\
\text { isoclinal folds with thin nanks and thick crests. Ductiles } \\
\text { low- and high-angle mylonitichlastomylonitic shear zones. }\end{array}$ & $\mathbf{M}$ & & & & $\begin{array}{l}\text { D1 } \\
\text { (D) }\end{array}$ & $\begin{array}{l}\text { D1 - Recumbent folding and migmatization } \\
\text { with biotite iso-orientated paraltel to } S \text { in the } \\
\text { neosom. Development of garnets shortly after } \\
\text { M1. }\end{array}$ \\
\hline
\end{tabular}

genesis), refining previous works of Coutinho (1972) and Carneiro (1983) (Table 5).

9. Basically, there are four models proposed to explain the evolution of the Ribeira Belt: (1) Continuous oblique convergence of continents in an E-W transpressional regime with an older stage of tangential oblique tectonic (thrust faulting) and a younger stage of strike-slip tectonic (Wernick et al. 1981, Ebert et al. 1996). The same strikes of the thrust and wrench fault systems suggest an about simultaneous (overlapping) development of thrust and transcurrent faults in a simple shear transpressional regime. There is a dominance of transcurrent over thrust faults, the latter reflecting the accommodation of the deformation by crustal shortening (Tikoff \& Teyssier 1994). (2) Continuous oblique convergence of continents in an initial E-W and final $\mathrm{N}-\mathrm{S}$ transpressional regime. The aim of this model is to explain the transversal D4 folding superimposed on the overall Ribeira NE-SW direction with the development of a final "egg box" (domes and basins) structure (Soares et al. 1990, Endo \& Machado 1993,1995, Machado \& Endo 1993, Machado 1997). (3) An initial E-W frontal shortening phase (with tectonic transport from SSE to NNW) followed by an oblique dextral strike-slip one. In this model the transpressional nature of the Ribeira belt was developed only during its latest evolutional phase and is, therefore, of only secondary importance (Heilbron et al. 1995). (4) The transcurrent faulting represents a younger stage of "lateral escape tectonics" following an older one of approximately frontal "convergence and collision tectonics" (Vauchez et al. 1992, Soares \& Rostirolla 1997).

10. For some authors the evolution of the Ribeira belt comprises at least two orogenies based mainly on geocronological data (Table 6). Clear integrated description of geological, sedimentary, tectonic, stratigraphic and magmatic data to support such proposals are either missing or not fully convincing.

11. Many authors proposed different tectonic and age classifications for the main episodes of granitoid emplacement of the Ribeira Belt. Three of them are summarised in Table 7 which shows missing consensus concerning the number of major emplacement episodes, their ages and characterisation based on deformation phases and metamorphic events. This is not surprising considering either Table 1 or the fact that even smaller RFB granitic plutons always show a rather complex structure (Wernick et al. 1993,1994,1995).

12. The evolution of the Ribeira Belt comprises four main stages: Rifting, Subduction, Continents Collision and Postcollisional Crustal identation \& Uplift. The main processes and rocks acting/produced during each evolutional stage are summarised in boxes 8 and 9 .
Table 5 - Relationships between deformation (foliation) and heat flux (porphyroblast genesis) in the São Roque domain, State of São Paulo. After Dantas, 1990.

\begin{tabular}{|c|c|c|c|c|c|c|c|c|c|}
\hline \multirow{8}{*}{ MINERALS } & \multicolumn{9}{|c|}{ DEFORMATION PHASES } \\
\hline & \multicolumn{3}{|c|}{ DI } & \multicolumn{2}{|c|}{ Dz } & \multicolumn{2}{|c|}{ D3 } & \multicolumn{2}{|c|}{ D4 } \\
\hline & \multicolumn{9}{|c|}{ DEFORMED SURFACES } \\
\hline & \multicolumn{3}{|c|}{ Si } & \multicolumn{2}{|c|}{ S2 } & \multicolumn{2}{|c|}{53} & \multicolumn{2}{|c|}{ S4 } \\
\hline & \multicolumn{9}{|c|}{ FOLDED SURFACES } \\
\hline & & & & \multicolumn{2}{|c|}{ Si } & \multicolumn{2}{|c|}{ S2 } & \multicolumn{2}{|c|}{ Ss } \\
\hline & \multicolumn{9}{|c|}{ STAGES OF DEFORMATION } \\
\hline & PRE & SYN & POST & SYN & POST & SYN & POST & SYN & POST \\
\hline SILLJMANITE & & $\ldots . . . . .$. & ........... & & & & & & \\
\hline GARNET & & $\ldots . . . .$. & .......... & ......... & ........ & & & & \\
\hline STAUROLITE & & .......... & ........... & $\ldots \ldots$ & & & & & \\
\hline OPAQUES & ......... & .......... & ............ & & & $\ldots . . . . . .$. & ............ & & \\
\hline BIOTITE & & $\ldots \ldots$ & ............ & & & .......... & .......... & & \\
\hline TOURMLALINE & & & & & & & ......... & .......... & \\
\hline MUSCOVITE & & .......... & & & $\ldots . . . .$. & & ........... & & \\
\hline DIOPSIDF: & & & & & $\ldots \ldots$ & $\ldots$ & ......... & ........... & \\
\hline K.FELDSPAR & & & & & & $\ldots \ldots$ & $\ldots . . . .$. & & \\
\hline
\end{tabular}

Detailed information concerning the Rifting stage are still fragmental and not yet clearly described. Therefore, this evolutional stage is not included in the considered boxes.

THE PRMS-590 The Pluriserial Ribeira Magmatic System-590 developed during the Post-Collisional Identation and Uplift evolutional stage of the Ribeira Belt and display following main characteristics:

01 - Age. The PRMS-590 acted mainly between 610 and 580 Ma ago (Vlach\&Cordani 1986,Teuppenhayn 1994, Heilbron et al. 1995, Siga Jr. 1995, Siga Jr. Et al. 1994, 1997, Topfner 1996, Kaul 1997, Janasi \& Vlach 1997, Janasi et al. 1997, Machado 1997, Wernick \& Topfner 1997)., by this the expression PRMS-590.

02 - Magmatic series. According to Wernick (1998a, b, 1999), the PRMS-590 comprise several rock groups (series), summarised below:

1. High-K calc-alkaline to dominantly alkali-calcic metaluminous to weakly peraluminous Caledonian I-type granitoids assembling (quartz) monzonites \& syenites and monzo-, syeno- and alkali-feldspar granites. More basic rocks are rare. Magmas are of lower crustal origin 
with an overall Peacock alkalinity index near $54, \mathrm{~K}_{2} \mathrm{O} / \mathrm{CaO}=1$ near $60 \% \mathrm{SiO}_{2}$ and ${ }^{87} \mathrm{Sr}^{86} \mathrm{Sr}_{(590)}$, between 0.7064 and 0.787 (Vlach \& Cordani 1986, Tassinari 1988, Artur et al. 1991, 1993, Artur \& Wernick 1993, Wernick 1996, Töpfner 1996, Wernick \& Teuppenhayn 1999, Wernick et al. 1998a, 1999b).

2. High-K alkali-calcic metaluminous to weakly peraluminous rapakivi suites comprising dominantly monzo-, syeno- and alkali-feldspar granites beside (quartz) monzonites \& syenites. More basic rocks are rare. Magmas are of lower crustal origin with an overall Peacock alkalinity index near 54 and $\mathrm{K}_{2} \mathrm{O} / \mathrm{CaO}=1$ near $60 \% \mathrm{SiO}_{2}$. A typical example of this group is represented by the Itu Province, State of São Paulo, SE Brazil, (Gama 1946, Pascholati et al. 1987, Godoy 1989, Kohler 1990, Pascholati 1990, Ruf 1990, Galembeck 1991, 1997, Galembeckefa/. 1991,1997. Wernick et al. 1991,1994,1997a, 1998a, 1999b, Rothmaier 1994). ${ }^{87} \mathrm{Sr}^{86} \mathrm{Sr}_{(585)}$ values range between 0.7066 and 0.7081 (Tassinari et al. 1988, Töpfner 1996) and the $\delta^{18} \mathrm{O}$ values are high $(+9.5 \%$, Zielenski 1993).

3. Metaluminous shoshonitic \pm fayalite \pm pyroxene \pm hornblende \pm biotite (quartz) monzonites \& syenites and monzo-, syeno- \& alkali feldspar granites intimately associated with those from group 4 and

Table 6 - Orogenies (names, ages, stages and relationships with the regional metamorphic events (Ml and M2) of the Ribeira (States of Rio de Janeiro, Espirito Santo and Minas Gerais) and Brasilia (State of Minas Gerais) belts, SE Brazil.

\begin{tabular}{|c|c|c|c|c|c|}
\hline \multicolumn{5}{|c|}{ RIBEIRA BELT } & \begin{tabular}{|c} 
BRASILIA \\
BELT
\end{tabular} \\
\hline $\begin{array}{c}\text { CAMPOS NETO } \\
\text { \& FIGUEIREDO } \\
\text { (19QS) }\end{array}$ & $\begin{array}{c}\text { WIEDEZMANN } \\
\text { (1993) }\end{array}$ & & $\begin{array}{c}\text { HEHBRRON at al. } \\
\text { (to9s) }\end{array}$ & RIBEI & Wo er at. \\
\hline $\begin{array}{c}\text { RIO DOCE } \\
\text { OROGENY } \\
5 \% 0-480 \mathrm{Ma} . \\
\text { Related to M2 }\end{array}$ & $\begin{array}{l}\text { RIO DOCE } \\
\text { OROGENY } \\
\text { S80-45AMm. }\end{array}$ & & 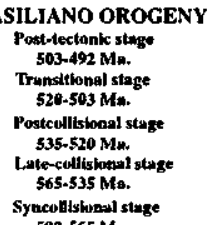 & $\begin{array}{c}\text { RIBEIRA } \\
\text { OROGENY } \\
\text { - } 570 \mathrm{Ma} . \\
\text { Related to M2 }\end{array}$ & \\
\hline $\begin{array}{l}\text { BRASILIANO } \\
\text { I OROGENY } \\
760-600 \mathrm{Ma} . \\
\text { Related to MI }\end{array}$ & & & 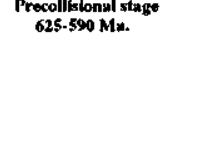 & & $\begin{array}{c}\text { BRASILIA } \\
\text { OROGENY } \\
\text { - } 600 \mathrm{Ma} . \\
\text { Related to Mt }\end{array}$ \\
\hline
\end{tabular}

with peraluminous granitoids in plutons with hyper-, trans- and subsolvus rocks, associated or not with basaltic to rhyolitic volcanics. Rare late mafic soda-minerals occur sometimes as well as intensive Na-metasomatism (albitization). Their isotopic data are quite similar to those of group 4 (Siga Jr. 1995, Siga Jr. et al. 1994, 1997, Kaul 1997). The most expressive association between groups 3 and 4 is the Serra do Mar Province, States of São Paulo, Parana and Santa Catarina, SE/S Brazil, which shows many features of other "younger granites" provinces (Wernick et al. 1999a) like the Nigerian Mesozoic plutono-volcanic rocks (Fitton \& Upton 1987, Bowden et al. 1987, Sylvester 1989, Bonin 1990). The rocks are derived dominantly from lower crustal melts produced by infiltration of gabbroic magmas and evolved by intensive fractionation and fluid-related metasomatism in part either to peraluminous or peralkaline ones (Halliday et al. 1981, Martin \& Bowden 1981, Bowden \& Kinnaird 1984, Wernick et al. 1998a).

4. High-K peralkaline mafic soda-minerals (aegirine \pm riebeckite \pm arfvedsonite \pm hastingsite) \pm fayalite \pm Ca-pyroxene \pm hornblende \pm biotite bearing (quartz) monzonites \& syenites and monzo-, syeno- \& alkali feldspar granites. These rocks are rather $\mathrm{V}, \mathrm{Ti}, \mathrm{Sr}$ and $\mathrm{Ca}$-poor and frequently show intensive albitization. Fluorite is a common accessory and the alkaline mafic minerals are of late crystallization. The rocks show $\varepsilon \mathrm{Nd}_{(60)}$ values between -8 and -13 , Lower Proterozoic $\mathrm{T}_{\mathrm{DM}}$ ages highly variable ${ }^{87} \mathrm{Sr}^{86} \mathrm{Sr}_{(590)}$ values between 0.7020 and 0.7177 (Siga Jr. 1995, Siga Jr. et al. 1994, 1997, Kaul 1997). The low

Table 8 - Evolutional stages and major processes of the Ribeira Belt.

\begin{tabular}{|c|c|c|}
\hline \multicolumn{3}{|c|}{ EVOLUTIONAL STAGES OF THE RIBEIRA BELT } \\
\hline $\begin{array}{l}\text { SUBDUCTION } \\
\text { (CONTINENTS } \\
\text { CONVERGENCE) }\end{array}$ & $\begin{array}{l}\text { CONTINENT-CONTINENT } \\
\text { COLLISION }\end{array}$ & $\begin{array}{l}\text { POSTCOLLISIONAL } \\
\text { IDENTATION \& UPLIFT }\end{array}$ \\
\hline \multicolumn{3}{|c|}{ PROCESSES } \\
\hline $\begin{array}{l}\text { 1. IJTHOSPHERIC } \\
\text { SURDUCTION }\end{array}$ & $\begin{array}{l}\text { 1. CRUSTAL, THICKENING \& } \\
\text { HINTERLAND EXTENSION }\end{array}$ & $\begin{array}{l}\text { 1. IOENTATION \& UPIJFT OF } \\
\text { CONTINENTAL CRUST }\end{array}$ \\
\hline $\begin{array}{l}\text { 2. UNDEFPPATING OF MAFIC } \\
\text { FERTILE MANTLE MAGMAS }\end{array}$ & $\begin{array}{l}\text { 2. INCOME OF MAFIC FERTIL } \\
\text { MANTLE MAGMAS }\end{array}$ & $\begin{array}{l}\text { 2. 1NCOME OF MAFIC FERTLLE } \\
\text { MANTLE MAGMAS EY } \\
\text { PRESSIUE, RELFASING } \\
\text { MELTING }\end{array}$ \\
\hline $\begin{array}{l}\text { 3. REGIONAI, CRUSTAL } \\
\text { UPHEATING RY GRANTTOID } \\
\text { MAGFAS \& CRUSTAL. } \\
\text { INTERSTACKLING: }\end{array}$ & 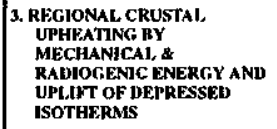 & $\begin{array}{l}\text { 3. LOCAT, MEITING OF STLLL, } \\
\text { HOT LOWWE CRUST HV } \\
\text { MAFIC MAGMA } \\
\text { INFILTRATION }\end{array}$ \\
\hline $\begin{array}{l}\text { 4. DHFORMATON INA } \\
\text { MAINIX } \\
\text { TRANSPRKSSTONAL, STRESS } \\
\text { RECIME }\end{array}$ & $\begin{array}{l}\text { 4. DEFORMATION WNA } \\
\text { MAINLY } \\
\text { TRANSPRESSIONAL TO } \\
\text { TRANSCURELNT STRESS } \\
\text { REGILE: }\end{array}$ & $\begin{array}{l}\text { 4. DEFORMATION IN A MA INLY } \\
\text { TRANSTENSIONAL TO } \\
\text { TENSIONAL STKESS REGIME }\end{array}$ \\
\hline
\end{tabular}

Table 7 - Classification and age for granitoids from the Ribeira Belt in the States of Rio de Janeiro (1,2) and São Paulo (Paranapiacaba domain) (3), based on relationships between emplacement episodes, folding (D) and faulting (D) phases and metamorphic events. Metamorphism: $M=$ regional; $M=$ retrograde; $m=$ contact; $m=$ dynamic (cataclastic). MIG = migmatization. $m$ is related with $D$.

\begin{tabular}{|c|c|c|c|c|c|c|c|}
\hline \multicolumn{3}{|c|}{ HEILBRON et al, 1995} & \multicolumn{3}{|c|}{ MACHADO, 1997} & \multicolumn{2}{|c|}{ HASUI, 1975} \\
\hline GROUP & AGE (Ma.) & TYPE & GROUP & AGE (Ma.) & TYPE & GROUP & TYPE \\
\hline $\begin{array}{c}v_{-} \\
\text {POST- } \\
\text { TECTONIC }\end{array}$ & 503-492 & $\begin{array}{c}\text { LATE/POST-D4 } \\
\text { + BASIC } \\
\text { MAGMATISM } \\
\end{array}$ & \multirow{2}{*}{$\stackrel{4-}{\text { POST }}$} & \multirow[t]{2}{*}{$520-480$} & \multirow[t]{2}{*}{ SYN-D4 } & \multirow{2}{*}{$\begin{array}{c}1-3 \\
\text { POST- } \\
\text { TECroNIC }\end{array}$} & \multirow{2}{*}{$\begin{array}{c}\text { POST-D3 } \\
\text { PRE-FINAL } D \\
\text { PRE-FINAL } m \\
\text { SYN-M } \\
\text { SYN-m2 }\end{array}$} \\
\hline $\begin{array}{c}v- \\
\text { TRANSITIONAL }\end{array}$ & $520-503$ & SYN-D 4 & & & & & \\
\hline \multirow{2}{*}{$\begin{array}{c}\text { IV. } \\
\text { POST- } \\
\text { COLLISIONAL }\end{array}$} & \multirow{2}{*}{$535-520$} & \multirow{2}{*}{$\begin{array}{l}\text { SYN-DJ } \\
\text { SYN=M2 }\end{array}$} & $\begin{array}{c}\overline{3} \\
\text { POST } \\
\text { COLLISIONAL }\end{array}$ & 530-520 & LATE-D3 & & \\
\hline & & & \begin{tabular}{c|}
$2 \cdot$ \\
LATE. \\
COLLISIONAL
\end{tabular} & $5901-570(\%)-531)$ & $\begin{array}{l}\text { SYN-D3 } \\
\text { SYN-M2 }\end{array}$ & & \\
\hline $\begin{array}{c}\text { III- } \\
\text { LATE- } \\
\text { COLLISIONAL }\end{array}$ & $565-535$ & $\begin{array}{c}\text { LATE-D2 } \\
\text { LATE M1 } \\
\text { + BASIC } \\
\text { MAGMATISM }\end{array}$ & & & & \multirow{2}{*}{$\begin{array}{c}1-2 \\
\text { SYN/LATE } \\
\text { TECTONIC }\end{array}$} & \multirow{2}{*}{$\begin{array}{l}\text { SYN-D2 } \\
\text { POST-M } \\
\text { SYN-m1 } \\
\text { SYN-m }\end{array}$} \\
\hline $\begin{array}{c}\text { ll- } \\
\text { SYN. } \\
\text { COLLISIONAL }\end{array}$ & $590-565$ & $\begin{array}{c}\text { SYN-D2 } \\
\text { MAIN M1 }\end{array}$ & $\begin{array}{c}1: \\
\text { SYN- } \\
\text { COLLISIONAL }\end{array}$ & $600-5901 / 570(?)$ & $\begin{array}{l}\text { SYN-D2 } \\
\text { SYN-M1 }\end{array}$ & & \\
\hline $\begin{array}{c}\text { l- } \\
\text { PRE- } \\
\text { COLLISIONAL }\end{array}$ & 625-590 & $\begin{array}{c}\text { SYN-D1 } \\
\text { PRE/EARLY M1 }\end{array}$ & $\begin{array}{c}1 . \\
\text { PRE- } \\
\text { COLLISIONAL }\end{array}$ & $6510(7)(621)-61) 0$ & PRE-D2 & $\begin{array}{c}\text { J-1 } \\
\text { PRE- } \\
\text { TECTONIC }\end{array}$ & $\begin{array}{l}\text { PRE-D1 } \\
\text { PRE-M } \\
\text { PRE-MIG. }\end{array}$ \\
\hline
\end{tabular}


Table 9 - Evolutional stages and granitoid types of the Ribeira Belt.

\begin{tabular}{|c|c|c|}
\hline \multicolumn{3}{|c|}{ EVOLUTIONAL STAGES OF THE RIBEIRA BELT } \\
\hline $\begin{array}{c}\text { SUBDUCTION } \\
\text { (CONTINENTS } \\
\text { CONVERGENCE) }\end{array}$ & $\begin{array}{l}\text { CONTINENT-CONTINENT } \\
\text { COLLISION }\end{array}$ & POSTCOLLISIONAL IDENTATION \& UPLIFT \\
\hline \multicolumn{3}{|c|}{ ROCKS } \\
\hline & & $\begin{array}{l}\text { K-RICH SERIES FROM THE PLURISERIAL } \\
\text { RIBEIRA MAGMATIC SYSTEM-590 }\end{array}$ \\
\hline $\begin{array}{l}\text { A.1. "WET \& DRY" CALC. } \\
\text { ALKALINE CORDILLERAN I. } \\
\text { TYPE GRANITES, OFTEN } \\
\text { HIGH-K. }\end{array}$ & $\begin{array}{l}\text { B.1. ALUMINOUS S-TYPE } \\
\text { GRANITES DERIVED } \\
\text { FROM COVER ROCKS. }\end{array}$ & $\begin{array}{l}\text { C.1. LATE HIGH-K CALC-ALKALINE TO } \\
\text { DOMINANTLY ALKALI-CALCIC } \\
\text { METALUMINOUS/WEAKLY PERALUMINOUS } \\
\text { CALEDONIAN I-TYPE GRANITIC SUITES. }\end{array}$ \\
\hline $\begin{array}{l}\text { A.2. BANDED MIGMATITES } \\
\text { DERIVED FROM A.1. } \\
\text { GRANITOIDS ALONG } \\
\text { DUCTILE HIGH. } \\
\text { TEMPERATURE THRUST } \\
\text { FAULTS. }\end{array}$ & $\begin{array}{l}\text { B.2. MIGMATITES } \\
\text { GENERATED BY PARTIAL } \\
\text { MELTING OF COVER } \\
\text { ROCKS. }\end{array}$ & $\begin{array}{l}\text { C.2. HIGH-K ALKALI-CALCIC } \\
\text { METALUMINOUS/WEAKLY PERALUMINOUS } \\
\text { RAPAKIVI GRANITIC SUITES. }\end{array}$ \\
\hline $\begin{array}{l}\text { A.3. IRREGULAR LENSES OR } \\
\text { HORIZONS OF } \\
\text { CHARNOCKITIC GNEISSES IN } \\
\text { "WET"A.1.GRANITOIDS } \\
\text { ALONG DUCTILE HIGH- } \\
\text { TEMPERATURE THRUST } \\
\text { FAULTS. }\end{array}$ & $\begin{array}{l}\text { B.3. MIGMATITES } \\
\text { GENERATED BY PARTIAL } \\
\text { MELTING OF A.1. } \\
\text { GRANITOIDS, A.2. } \\
\text { BANDED MIGMATITES } \\
\text { AND A.4. GNEISSES }\end{array}$ & $\begin{array}{l}\text { C.3. V, TI AND SR.POOR HIGH-K PERALKALINE } \\
\text { (QUARTZ) MONZONITES \& SYENITES, AND } \\
\text { MONZO., SYENO-\& ALKALI FELDSPAR } \\
\text { GRANITES WITH. MAFIC SODA-MINERALS } \\
\text { FAYALITE } \pm \text { PYROXENE } \pm \text { HORNBLENDE } \pm \\
\text { BIOTITE. }\end{array}$ \\
\hline $\begin{array}{l}\text { A.4. GNEISSES DERIVED FROM } \\
\text { A.1. GRANITOIDS ALONG } \\
\text { DUCTILE MEDIUM. } \\
\text { TEMPERATURE THRUST AND } \\
\text { WRENCH FAULTS. }\end{array}$ & $\begin{array}{l}\text { B.4. MIGMATITES } \\
\text { GENERATED BY PARTIAL } \\
\text { MELTING OF OLDER } \\
\text { BASEMENT ROCKS AND } \\
\text { A.S. GNEISSES. }\end{array}$ & $\begin{array}{l}\text { C.4. Y, TI AND SR-POOR SHOSHONITIC (QUARTZ) } \\
\text { MONZONITES \& SYENITES, AND MONZ0-, } \\
\text { SYENO-\& ALKALI FELDSPAR GRANITES, } \\
\text { SOMETIMES WITH } \pm \text { FAYALITE } \pm \text { PYROXENE } \\
\text { + HORNBLENDE } \pm \text { BIOTITE AND RARE LATE } \\
\text { MAFIC SODA MINERALS. }\end{array}$ \\
\hline $\begin{array}{l}\text { A.5. BANDED MIGMATITES \& } \\
\text { GNEISSES DERIVED FROM } \\
\text { OLDER BASEMENT-ROCKS } \\
\text { ALONG DUCTILE } \\
\text { HIGH/MEDIUM. } \\
\text { TEMPERATURE THRUST AND } \\
\text { WRENCH FAULTS. }\end{array}$ & $\begin{array}{l}\text { B.5. GNEISSES DERIVED } \\
\text { FROM A.1. TO A.S. AND } \\
\text { B.1. TO B.4. ROCKS } \\
\text { ALONG DUCTILE } \\
\text { MEDIUM-TEMPERATURE } \\
\text { WRENCH FAULTS. }\end{array}$ & $\begin{array}{l}\text { C.5. V, TI AND SR-RICH METALUMINOUS K- } \\
\text { ALKALINE PLUTONS WITH KERSANTITIC \& } \\
\text { APPENITIC AFFINITIES COMPRISING SUITES } \\
\text { OF } \pm \text { (QUARTZ) GABBROS \& } \\
\text { MONZOGABBROS } \pm \text { (QUARTZ) } \\
\text { MONZODIORITES \& DIORITES } \pm \text { (QUARTZ) } \\
\text { MONZONITES \& SYENITES } \pm \text { GRANITES. } \\
\text { C.6. OVER TO UNDERSATURATED } \\
\text { ULTRAPOTASSIC ROCKS INCLUDING } \\
\text { MAINLY V, TI AND SR-RICH } \\
\text { METALUMINOUS TO WEAKLY } \\
\text { PERALKALINE (OPX) MONZONITES \& } \\
\text { SYENITES. }\end{array}$ \\
\hline
\end{tabular}

${ }^{87} \mathrm{Sr} /{ }^{86} \mathrm{Sr}$ values are inherited from mantle derived magmas and extensive fractional crystallization has depleted them to such a low level that small amounts of crustal or selective ${ }^{87} \mathrm{Sr}$ contamination can account for the high initial Sr isotopic ratios. Also the action of fluids may be responsible for the development of their peralkaline nature (Martin \& Bowden 1981, Halliday et al. 1981, Bowden \& Kinnaird 1984, Kinnaird et al. 1985, Martin 1989, Bowden et al. 1990, Bedard 1990, Greaser et al. 1991, Wernick et al. 1999a).

5. K-alkaline basic to acid metaluminous plutons comprising \pm (quartz) gabbros \& monzogabbros \pm (quartz) diorites \& monzodiorites \pm (quartz) monzonites \& syenites and granites with or without small amounts of late crystallised mafic soda-minerals (aegirine, hastingsite). This group with features of calc-alkaline kersantitic and appenitic lamprophyres (Wernick \& Menezes 1998) shows V/Ti and Zr/Y:Zr ratios in part higher than those for ocean island and within plate basalts (Wernick, unpublished data). The best studied body of this group is the highly complex Piracaia pluton, State of São Paulo, SE Brazil, considered as derived from an enriched mantle source (Campos Neto \& Artur 1983, Janasi 1986, Janasi \& Ulbrich 1987, Artur et al. 1994, Gomes \& Platevoet 1994, Wernick et al. 1997b, 1999 a, Wernick \& Menezes 1997, 1998) as well as the Santa Angelica pluton, State of Espirito Santo, (Horn \& Weber-Diefenbach 1987, Schmidt-Thome \& Weber-Diefenbach 1987). The Piracaia pluton shows ${ }^{87} \mathrm{Sr}^{86} \mathrm{Sr}_{(600)}$ ratios between 0.704 and 0.705 for late evolved rocks in part affected by and recrystallised in shear zones (Janasi et al 1993).
6. Over- to undersaturated metaluminous/weakly peralkaline ultrapotassic rocks including \pm orthopyroxene monzonites \& syenites akin to calc-alkaline lamprophyric minette suites. Typical examples are the Capituva and Pedra Branca plutons, State of Minas Gerais, SE Brazil, also considered as derived from an enriched mantle source (Winters 1981, Janasi 1992, 1993, Janasi et al. 1993, Topfner 1996, Wernick \& Menezes 1997, 1998, Wernick et al. 1997c, 1998b, 1999 a). The rocks have $\varepsilon \mathrm{Nd}_{(612)}$ and ${ }^{87} \mathrm{Sr}^{86} \mathrm{Sr}_{(612)}$ values of 7 to -10 and 0.7072 and 0.7078 ,respectively, and $\mathrm{T}_{\mathrm{DM}}$ ages between 1.5 and $1.7 \mathrm{Ga}$. (Winters 1981, Topfner 1996, Janasi \& Vlach 1997).

03 -Stress regime. The emplacement of the PRMS-590 plutons and associated volcanics occurred under a dominantly transtensional to tensional stress regime expressed by their many neutral or prolate Flinn deformation ellipsoids (Ebert et al. 1996, Ferreira 1997, Wernick, unpublished data).

04 - Sizes, shapes, spatial distribution and contacts. The sizes of the PRMS-590 plutons are highly variable ranging from less than 10 up to more than $400 \mathrm{~km}^{2}$ in composite bodies but there is a clear dominance of intrusions between 30 and less than $100 \mathrm{~km}^{2}$. Their shapes are elliptical, rounded or irregular. Elliptical bodies frequently results from the emplacement of successive magma pulses along transtractive faults successively reactivated during this process. Rounded bodies often cut or are associated with transtensional and tensional faults or zones of tectonic weakness. Irregular bodies are of two types. In the first, the plutons are cut by syn- to post-emplacement 
tensional faults with the development of partially polygonal shapes (Wernick 1983). In some cases lower levels of the plutons are uplifted by a "stair case tectonic" allowing the study of their vertical magmatic architecture (Wernick et al. 1993). The second type results in bodies that underwent post-emplacement drag deformations by reactivation of former wrench faults with the development of arched, "S"," hockey stick" and "boomerang" shapes (Kaul 1997, Wernick \& Teuppenhayn 1999). The plutons occur either as isolated bodies or as aligned "pearl strings" on or along expressive zones of crustal weakness. In other cases their areal distribution is controlled by two or even three crossing fault systems so that several plutons are clustered in relatively small areas around certain particular lineaments intersections. Rarely also a regular migration of successive plutons is observed with the younger plutons cutting or neighbouring the older ones. Apparently this process reflect the progressive implantation of a transtractive stress regime in older long-lived tectonic lineaments An expressive example is the polycentred Itu rapakivi complex, State of São Paulo (group 2), a assemblage of four plutons. From the above description results that the contacts of the PRMS-590 plutons are either dominantly magmatic or tectonic and, most frequently, mixed.

05 - Emplacement controls. Plutons are emplaced mainly either on or near to faults or tectonic lineaments (Wernick et al. 1993,1995, Ferreira 1997) and only rarely in arched structures produced by the $3^{\text {rd }}$ (and last) regional open and long waved folding phase (Hasui 1975, Godoy 1989). In relation to wrench faults the following cases are observed: (1) plutons are cut by and displaced along wrench faults; (2) cut but little displaced by wrench faults; (3) emplaced along wrench faults but not affected by younger reactivation; (4) cut wrench faults. In all these cases the plutons can be cut by younger normal faults including a "stair case tectonic" reflecting the development of regional horst and graben structures. Concerning the host-rocks, the PRMS-590 plutons cut (1) low grade Brasiliano metasedimentary-volcanic rocks; (2) medium/high grade Brasiliano gneisses and migmatites; (3) synconvergent Brasiliano calc-alkaline batholith and (4) medium/high grade Pre-Brasiliano basement rocks.

06 -Emplacement temperature: In deep-seated basic plutons occasionally a small outer ring of molten country-rocks surrounds the bodies (e.g. the Santa Angelica pluton of group 5, State of Espfrito Santo, SE Brazil, Horn \& Weber-Diefenbach 1987, Schmidt-Thome \& Weber-Diefenbach 1987). In other cases the country-rocks became softened by magmatic heat transfer and are moulded concordantly around the plutons and with local spots of anatexis (e.g. the Capituva intrusion, group 6, State of Minas Gerais, SE Brazil, Janasi 1992) or the plutons show very strong flow structure parallel to their contacts (e.g. Pedra Branca pluton, group 6, State of Minas Gerais, Winters 1981). These features indicate not only the high temperature of the intrusion but also the hot nature of deeper crustal levels during the emplacement. The high temperature of the magmas is reinforced in high-level plutons with large rounded quartz crystals and their association with volcanic rocks either in their neighbourhood or as cover. Good examples are the Serra do Mar Province and the Itu rapakivi complex, where volcanic rocks now occur as pebbles in Carboniferous sediments which cover partially or occur near the intrusion. The high temperature is also reflected by up to pyroxene hornfels facies contact aureoles as in the case of the Sorocaba rapakivi pluton, State of São Paulo (Godoy 1989). The high velocity and forceful emplacement is suggested in some cases by larger brecciated contacts as in the case of the Cabreuva intrusion from the Itu rapakivi complex, State of São Paulo (Galembeck 1991, 1997, Wernick et al. 1997a) as well $f_{2}$ changes in the contact zones of some plutons where magnetite "oxyexsolved" to hematite and late stage ilmenite exsolved to ilmenite-hematite (Wernick, unpublished data). Another indication is the high frequency of disrupted synintrusive basic dikes which in some cases clearly occur between successive magmatic cycles which built up the major composite plutons (Wernick et al. 1993, Ferreira \& Wernick 1991, Wernick \& Ferreira 1993, Ferreira 1997).

07 - Some features of the magmatic series. Each magmatic series of the PRMS-590 comprises either chemically expanded or restricted plutons, the latter silica-rich (Galembeck \& Wernick 1998a, Wernick et al 1997a, b, Kaul 1997). In silica-rich plutons there is often a negative correlation between silica and alkalis, a feature which can be debt to the presence of an expressive fluid phase during magmatogenic processes (Rogers \& Satterfield 1994). Plutons of six described groups often contain F-rich biotite beside fluorapatite, fluorite and tourmaline (Janasi 1986,1992, Galembeck 1997, Kaul 1997, Wernick
\& Teuppenhayn 1999). An intimate spatial association between plutons of the different series comprised by the PRMS-590 is frequent Outstanding is the association between plutons from group 1 with all other either in nearby plutons or in complex pluriserial ones. The synconvergent calc-alkaline Socorro batholith (States of São Paulo and Minas Gerais) is cut by plutons from groups 1 and 5 (Artur et al. 1993); in the Serra do Mar Province plutons from groups 1, 3 and 4. occur side by side (Kaul 1997, Wernick etal. 1999a) and the multiple centred Itu complex is built up by three plutons of group 2 and one of group 1 (Galembeck 1997, Galembeck \& Wernick 1998b).

08 - Magmatic architecture of the plutons. The plutons are mainly polyphasic, built up by several magmatic pulses expressed as magmatic facies. Even at first glance apparently homogeneous larger bodies reveal this feature through careful faciological mapping (Wernick et al. 1993,1995, Wernick \& Ferreira 1993). The income of successive pulses is clearly related to repeated reactivation of expressive shear zones. Comparative studies of different plutons along the Taxaquara and Jundiuvira faults, State of São Paulo, allowed the determination of five main pulses: (1) initial; (2) main; (3) lateral accretion; (4) income of smaller stocks and (5) final (Wernick et al. 1993,1995, Ferreira 1997). By this regional feature the determination of relative age of plutons linked with expressive zones of tectonic weakness based on the number of assembled pulses became possible and an example is provided by the successively slightly younger Sorocaba, São Francisco and Itu rapakivi granites, State of São Paulo, linked to the Taxaquara-Jundiuvira megafaults system (Wernick et al 1994).

09 - Alkalinity. In complex plutons built up by several magmatic facies an increase of their alkalinity occurs in successively younger pulses (Galembeck 1997, Ferreira 1997, Wernick et al 1997a). The same feature is observed at the level of entire plutons in multiple complexes built up by 2 or more amalgamated intrusions (Galembeck 1997, Galembeck \& Wernick 1998b). This characteristic is also observed on a regional scale in magmatic provinces in which plutons belonging to a same magmatic series show variable degrees of alkalinity (Kaul 1997, Wernick et al. 1997a, Galembeck \& Wernick 1998b).

10 - Geotectonic environment. The PRMS-590 was developed during the Post-Collisional Crustal Identation \& Uplift-stage of the Ribeira Belt. In discrimination diagrams for K-rich rocks (Miiller et al 1992) the magmatic series 1 to 5 plot dominantly in the field for volcanic arc related magmatism and only the ultrapotassic rocks from group 6 cross the boundary between the arc-related and (possibly) the within plate magmatism field (Wernick et al. 998 a, b, 1999a, b).

11 - Origin and evolution. The PRMS-590 comprises magmas either of lower crustal origin or derived from a secondary enriched mantle, the former represented by plutons from groups 1,2 and 3 and the latter by groups 4,5 and 6 . The enriched mantle was probably produced by the intense calc-alkaline magmatism during the Subduction stage of the Ribeira Belt (Wernick et al. 1997c, 1998a, b). Many plutons representing the 6 magmatic series comprised by the PRMS590 clearly show two main evolutional processes: crustal assimilation (A) and crystal fractionation (CF) which results in combined ACF processes as shown by geological, petrographic, chemical and isotopic data (Tassinari 1988, Töpfner 1996, Wernick et a/.1997b, 1998a, b, 1999a, Wernick \& Menezes 1998, Wernick \& Teuppenhayn 1999). The assimilation is indicated by mixed zircon populations (Töpfner 1996); frequent strongly assimilated upper crustal enclaves (Wernick \& Teuppenhayn 1999); frequent B-rich (tourmaline) residual magmas in bodies cutting volcanic/deep marine metassediments (Artur et al 1992, Andrade et al 1994, Ferreira 1997, Wernick \& Teuppenhayn 1999); the presence of garnet and andaluzite/sillimanite in granitic zones surrounding major metassedimentary enclaves (Godoy 1989); high $\mathrm{Ba} / \mathrm{Y}$ relationships (Wernick et al. 1999b); magnetite oxyexsolved to hematite and late stage ilmenite exsolved to ilmenite-hematite (Wernick, unpublished data); upper crustal normalised spider diagrams (Galembeck 1997, Wernick et al 1999b); high Ce/Yb:Ta/Yb ratios in mantle derived suites (Wernick \& Menezes 1998) etc. Also fluids play an important role in the genesis and final evolution of the plutons as shown by increasing $\mathrm{Rb} / \mathrm{K}$ and $\mathrm{Hf} / \mathrm{Zr}$ relationships in increasing younger magmatic pulses as well as abundant fluorite, the negative correlation between silica and alkalis in silica-rich bodies and by final tourmalinization, silicification, albitization, pneumatolitic/hydrothermal sulfides and oxydes, etc. (Wernick \& Teuppenhayn 1999, Wernick et al 1999b). Through albitization and late mafic Na-minerals crystallization some of the Ca-poor shoshonitic granites of group 4 underwent 
possible change of its metaluminous nature to a peraluminous/peralkaline ones. In some cases the extreme final silica-enrichment arrived the quartzolitic field, with the production of porphyritic lavas with abundant partially resorbed former high- $T$ quartz phenocrysts in a fine quartz-rich and feldspar-poor matrix as in the case of the Itu rapakivi complex. Also in this intrusion quartz-rich plutonic rocks show a typical dendritic texture built up by strings of rounded quartz forming an irregular and discontinuous net which holes are filled with anhedral K-feldspar.

The intensive association between plutons from series 1 and 2 suggest that rapakivi granites related to fold/shear belts may represent a particular evolutional path (by MASH and ACF processes) of the Caledonian I-type magmatism which comprises some plutons with rapakivi-like geochemical features and both series are also characterised by continuous alkalinity increasing from older to younger plutons (Wernick et al 1998a, 1999b). The close spatial association of plutons from series 1 to 6 indicates the simultaneous melting of mantle and deep crustal protoliths. The melting of the latter ones can be debt to an upwelling of the isotherms during the post-collisional tectonic relaxation with the formation of local "heat pillows" and/or the infiltration of mantle derived magmas in the lower crust.

12 - Economic aspects. Up to latter-days known mineralizations associated with plutons of the PRMS-590 are poor and controlled mainly by (1) the serial character of the magmatisms; (2) type of assimilated country-rocks; (3) degree of fractionation of the successive magma pulses and their fluid contents; (4) interplay between magmatic and tectonic processes. Examples are the high $\mathrm{Cu}$ and $\mathrm{Zn}$ concentrations in cumulatic rocks from the Piracaia pluton and high Gd values in its final acid phases (Wernick \& Menezes 1998) and the B-enrichment in late facies of plutons cutting the São Roque Group, State of São Paulo, can be debt to the assimilation of underlying volcanoclastic, chemical and deep marine sediments (Wernick \& Teuppenhayn 1999).

Due to their emplacement under transtensional to tensional stress regime, many of the plutons facies are rather homogeneous concerning their modal compositions, textures, structures, colours, etc. These features as well as the large textural and colour varieties among the plutons makes the PRMS-590 a target of the dimension stone industry (Soave \& Wernick 1997, Artur et al 1998a, b).

DISCUSSION AND CONCLUSIONS The spatial distribution of the PRMS-590, spread over the whole Ribeira Belt from the Sate of Espirito Santo, SE Brazil to Uruguay, points to rather uniform tectonic and thermal conditions in a very large area between about 615 and 575 $\mathrm{Ma}$ ago. The tectonic features at that time were characterised by simultaneous large horizontal and uplift movements of crustal blocks with the development of expressive horst and graben structures/monoclines and pull-apart basin. Some of these tectonic depressions acted as bassinets for the deposition of the erratic and mainly conglomeratic basal strata of the Parana basin. The transtensional and tensional deep faults allowed the ascent of magmas, the genesis of mantle derived magmas by pressure releasing processes and the generation of magmas with geochemical features of still dominantly magmatic arc magmatism. The numerous reactivation of the faults imply in successive draining of magma chambers during their evolution resulting in the complex polyphasic structure of the plutons. The successive tectonic sealing and draining besides the recharging of the chambers also promote the assimilation of crustal material with resulting ACF processes. By this the interpretation of the still scarce isotopic data for plutons of the PRMS-590 needs caution. The polyphasic plutons defined two different evolutional trends. The first is defined by lines connecting the most primitive rocks of the successive pulses and the second by lines linking all rocks of each pulse (Wernick \& Menezes 1997, 1998, Wernick et al. 1997b, c, 1999a). A hot lower crust which allowed the melting of orthogneisses to produce the high-K alkali-calcic Caledonian I-type and Rapakivi granites is also supported by typical features related with deep-seated plutons (melting of the country-rocks at the contacts; moulding of the country-rocks concordantly around the plutons; very strong and nearby transplutonic flow structure, etc.). All these facts point to the internal coherence of the PRMS-590 once analysed under integrated geological, tectonic, petrographic, chemical and isotopic points of view.

Acknowledgements To $\mathrm{CNPq}$ for supporting this work trough grant n ${ }^{\circ} 300562 / 89-6(\mathrm{RN})$.

\section{References}

Andrade, F. R. D.; Artur, A. C.; Wernick, E. 1994. Caracterizacao facio!6gica do Complexo Granit6ide Sao Roque, SP. Geociencias, Sao Paulo, 13 (1): 185-212.

Artur, A. C. 1988. Evolitffio policiclica da infra-estrutura daporcao sul de Minus Gerais e regides adjacentes do Estado de Sao Paulo. PhD-thesis, Institute de Geociencias, USP, 231 pp, Sao Paulo, Brazil.

Artur, A. C. \& Wernick, E. 1993. Relacoes temporais entre tectonica e magmatismo no complexo granit6ide Socorro (Estados de Sao Paulo e Minas Gerais, Brasil). Primer Simposio Internacional del Neoproteroz6ico-Cambrico de la Cuenca del Prata, Resumenos extensos, DINAMIGE-Facultad de Agronomia, Montevideu, Uruguai. I, Trabalho 7,7 pp.

Artur, A. C.; Ebert, H. D.; Wernick, E. 1991. Magmatismo e tectonica no Complexo Socorro (SP/MG). Atas II Simp. Geol.Sudeste, 105-112, SBG (nucleos SP/RJ-ES), Sao Paulo, SP, Brasil.

Artur, A. C. Wernick, E.; Andrade, F. R. D. de 1992. Turmalina granitos dos grupos Sao Roque e Acungui, Estado de Sao Paulo. An 37 Congr. Bras. Geoi, 1:354-355, SBG, Sao Paulo, SP, Brasil.

Artur, A. C.; Wernick, E.; Kawashita, K. 1988. Geocronologia das unidades lito-estratigraficas do embasamento cristalino da regiao sul de Minas Gerais e areas adjacentes do Estado de Sao Paulo. An. 35 Congr. Bras. Geol.,, 6:2854-2869, SBG, Belem, PA, Brasil.

Artur, A. C.; Wernick, E.; Rodrigues, E. de P. 1998. Mapa provisional de granitos ornamentais no Estado de Sao Paulo. An. XL Congr. Bras. Geol., SBG, 318, Belo Horizonte, MG, Brasil.

Artur, A. C.; Wernick, E.; rodrigues, E. de P. 1998b. Series granitdides e suas implicates como rochas ornamentais. An. XL Congr. Bras. Geol, SBG, 325, Belo Horizonte, MG, Brasil.

Artur, A. C.; Wernick, E.; Hormann, P. K.; Weber-Diefenbach, K. 1993. Associates plutonicas do Complexo Granit6ide Socorro (Estados de Sao Paulo e Minas Gerais, SE Brasil). Rev. Bras. Geoc., 23 (3): 265-273, SBG, Sao Paulo, SP, Brasil.

Artur, A .C.; Wernick, E.; Souza, S. C. A. de; Weber-Diefenbach, K. 1994. Tipologia de zircao e quimismo do complexo monzonftico-monzodiorftico Piracaia, SP. Geociencias (UNESP), 13(1): 167-173.

Bedard, J. 1990. Enclaves from the A-type granite of the Megantic Complex, White Mountain Magma Series: clues to granitic magma genesis. J. Geophvx. Res., 95: 17797-17819.

Bonin, B. 1990. From orogenic to anorogenic settings: evolution of granitoid suites after a major orogenesis. Geol. Journal, 25: 27-31.

Bowden, P. \& Kinnaird, J. A. 1984. The petrology and geochemistry of alkaline granites from Nigeria Phys. Earth Planet Int 35: 199-211.

Bowden, P.; Black, R.; Martin, R. F. et al. 1987. Niger-Nigerian alkaline ring complexes: a classic example of African Phanerozoic anorogenic mid-plate magmatism. In: Fitton, J. and Upton, B. J. G. (eds.) Alkaline Igneous Rocks, Geol. Soc. Sp. Publ, 30: 357-379.
Bowden, P.; Kinnaird, J. A.; Diehl, M.; Pirajno, F. 1990. Anorogenic granite evolution in Namibia - a fluid contribution. Geol. Journal, 25: 381-390.

Brown, M. 1994. The generation, segregation, ascent and emplacement of granite magma: the migmatite-to crustally-derived granite connection in thickened orogens. Earth-Sci. Rev., 36: 83-130

Capos Neto, M. C. \& Artur, A. C. 1983. A sufte quartzo monzonftica a dioritica de Piracaia, SP. Atas 4"Simp. Reg.Geol., 47-60, SBG /NSP, Sao Paulo, SP, Brasil.

Capos Neto, M. C. \& Basei, M. A. S. 1983. Evolufao estrutural brasiliana do nordeste de Sao Paulo: dobramentos superpostos e esbocos estratigraficos e tectonico. Atas 4" Simp. Reg. Geol., SBG, 4: 61-78, Sao Paulo, SP, Brasil.

Capos Neto, M. C. \& Basei, M. A. S. 1983b. A importancia dos falhamentos transcorrentes na configurafao do Prd-Cambriano entre Sao Jos6 dos Campos e Amparo (SP). Atas $4^{\circ}$ Simp. Reg. Geol., SBG, 4 : 79-90,

Capos Neto, M.C. \& Figueiredo, M. C. H. de. 1992. A orogenese Rio Doce. Bol. Resumos Expandidos, 37 Congr. Bras. Geol., 1; 276-277, SBG, Sao Paulo, SP, Brasil.

Capos Neto, M.C. \& Figueiredo, M. C. H. de. 1995. The Rio Doce orogeny, Southeastern Brazil. J. South Amer. Earth Sci., 8(2): 143-162.

Capos Neto, M.C.; Perrota, M. M.; Pellogia, A. U. G.; Figueiredo, M. C. H. de - 1990 - A porcao ocidental da faixa Alto Rio Grande (SP-MG). An. 36 Cong. Bras. Geol, SBG, 6 : 2615-2630, Natal, RN, Brasil.

Carneiro, C. D. R. 1983. Andlise estrutural do Grupo Sao Roque na faixa entre o Pica do Jaragud e a Serra dos Cristais, SP. PhD-thesis, Inst. Geociencias, USP, 155 pp, Sao Paulo, SP, Brasil.

Correa-Gomes, L.C. 1995. The mafic dyke swarm along the coastline of Bahia state, Brazil: A attempt of continental breakup between South America and Africa $1.0 \mathrm{Ga}$ ago? Third International Dyke Conference. Session A II-Geodinamic significance of dykes-regionaloverviews, Jerusalem, Israel, p 19

Correa-Gomes, L.C. \& Oliveira, E. P. 1997. O enxame radial gigante de diques maTicos da provfncia Bahia-Congo. ImplicafSes reo!6gicas e tectonicas da presenca de uma pluma mantelica na interfacie America do Sul-Africa, 1.0 Ga atras. Bol. Resumos VI Simp6sio Nacional de Estudos Tectonicos, 52-55, Piren6polis, GO, Brasil.

Correa-Gomes, L. C.; Tanner de Oliveira, M. A. F.; Motta, A. C; Cruz, M. J. M. 1996 Provincia de Diques Mdficos do Estado da Bahi: Mapas, Estdgio Atual do Conhecimento e Evolucao Temoporal. Superintendencia de Geologia e Recursos Minerals, Salvador, BA, Brasil, 144 pp.

Courinho, J. M. V. 1972. Petrologia do PrS-Cambriano de Sao Paulo e arredores. Boletim IG-USP, 3: 5-100.

Creaser, R. A.; Price, R. C.; Wormald, R. J. 1991. A-type granites revisited: assessment of a residual-source model. Geology, 19: 163-166.

Dantas, A. S. L. 1990. Geologia da Faixa Sao Roque e intrusivas associadas entre Sao paulo e Mairipora, Norte de Sao Paulo, SP. M.Sc.-thesis, Inst. Geociencias, USP, Sao Paulo, Brasil, 199+21 pp. 
Ebert, H. D.; Chemale, F. Jr.; Babinski, M.; Artur, A C.; Van Schmus, W. R. 1996. Tectonic setting and $\mathrm{U} / \mathrm{Pb}$ zircon dating of the plutonic Socorro Complex in the transpressive Rio Parafba do Sul shear belt, SE Brazil. Tectonics, 15 (2): 688-699.

Endo, I. \& Machado, R. 1993. Sistema de cisalhamento transatlantico: um modelo tectonico transpressional para o Neoproterozóico do Brasil oriental. Bol. Resumos $4^{\circ}$ Simpósio National Estudos Tectonicos, 356-359, Belo Horizonte, MG, Brasil.

Endo, I. \& Machado, R. 1995. Neoproterozoic continental-scale transpressional megazone in Eastern Brazil. Abstract $12^{\text {Th }}$ Int. Conference on basement tectonics.. 34-35, Oklahoma, USA.

Ferreira, C. J. 1997. Geoquimica e andlise da deformação do Complexo Itaqui. SP. evolução de granitos cálcio-alcalinos poli-intrusivos. Ph.D.-thesis. Inst. Geoc. Cienc. Exatas, UNESP, 272 pp., Rio Claro, SP, Brasil.

Ferreira, C. J. \& Wernick, E. 1991. Petrografia da suíte intrusiva Itaqui, SP. Atas $2^{\circ}$ Simp. Reg. Geol. Sudeste, SBG, 1: 121-129, Sao Paulo, SP, Brasil.

Fitton, J. G. \& Upton, B. G. J. 1987. Alkaline Igneous Rocks, Geol. Soc. Sp. Publ., 30 Blackwell Scientific Publications, Oxford, 568 pp.

Fossen, H. \& Tikoff, B. 1993. The deformation matrix for simultaneous simple shearing, pure shearing and volume change, and its application to transpression-transtension tectonics. J. Struct. Geol., $15(3 / 5):$ 423-422.

Galembeck, T. M. B. 1991. Aspectos geológicos, petrográficos e geoquímicos da intrusão Cabreuva, complexo granitóide Itu (SP). M. Sc. thesis, Inst. Geociências e Ciências Exatas, UNESP, 195 pp., Rio Claro, SP, Brasil.

GALEMBECK, T. M. B. 1997. O complexo múltiplo centrado pluriserial Itu, SP. PhD Thesis, Inst. Geociências e Ciências Exatas, UNESP, 352 pp., Rio Claro, SP, Brasil.

Galembeck, T. M. B. \& Wernick, E. 1998. As séries magmáticas álcali-cálcicas do Sistema Magmático 590 do Cinturão Ribeira. Adas II Congr.Uruguayo Geol.: 269-273, Punta del Este, Uruguay.

Galembeck, T. M. B. \& Wernick, E. 1998b. Tipos de plutons rapakivi na Província Itu, SP. An. XL Congr. Bras. Geol., SBG, 519, Belo Horizonte, MG, Brasil.

Galembeck, T. M. B.; Wernick, E.; Artur, A. C. 1991. Estruturação faciológica e petrografi da intrusão Cabreúva, Complexo rapakivi, Itu, SP. Atas $2^{\circ}$ Simp. Reg. Geol. Sudeste, 1: 1130120, SBG, São Paulo, SP, Brasil.

Galembeck, T. M. B.; Werneck, E.; Hermann, P. K. 1997. Chemistry of biotites and whole rocks from the rapakivi Itu complex, State of São Paulo, SE Brazil. An. Acad. Bras. Ci., 69 (3): 415-429, SBC, Rio de Janeiro, RJ.

Gama, R. S. da. 1946. O estudo da jazida de wolframita de Inhandjara. Boletim da Faculdade de Filosofia, Ciências e Letras da Universidade de São Paulo, LX (Mineralogia 8), São Paulo, Brasil, 95 pp.

Godoy, A. M. 1989. Caracterização faciologica, petrográfica e geoquímica dos Maciço Sorocaba e São Francisco. PhD-thesis, Inst. Geociências, USP, São Paulo, SP, Brasil.

Gomes, E. P. \& Platevoet, B. 1994. O complexo acido-básico de Piracaia - SP -representação de um magmatismo de afinidade shoshonítica do Ciclo Brasiliano. An. 38. Congr. Bras. Geol., 3: 32-34, SBG, Balneário de Camburiú, SC, Brasil.

Halliday, A. N.; Stephens, W. E.; Harmon, R. S. 1981. Isotopic and chemical constraints on the development of peraluminous Caledonian and Acadian granites. Can. Mineral., 19: 205-216.

Harland, W.B. 1971. Tectonictranspression in Caledonian Spitsbergen. Geol. Mag., 108 (1): $27-42$.

Harley, S. L. 1989. The origin of granulites. A metamorphic perspective. Geol. Mag., 126: 215-240.

Hasui, Y. 1975. Evolução polifásica do Pré-Cambriano a oeste de São Paulo (SP). Bol. IG-USP, 6: 95-108

Heilbron, M. 1993. Evolução Tectono-metamórfica da seção Bom Jardim de Minas (MG) - Barra do Pirai (RJ), Setor Central da Faixa Ribeira. PhD-thesis, Institute de Geociências, USP, São Paulo, SP, Brasil, 268 p.

Heilbron, M.; Valeriano, C. de M.; Valladares, C. S.; Machado, N. 1995. A orogênese Brasiliana no segmento central da Faixa Ribeira, Brasil. Rev. Bras. Geol., 25 (4): 249-266.

Horn, H. A. \& Weber-Diefenbach, K. 1987. Geochemical and genetic studies of ghree invers zoned intrusive bodies of both alkaline and calc-alkaline composition in the Ribeira mobile belt (Espfrito Santo, Brazil). Rev. Bras. Geoc., 17 (4): 488-497.

Janasi, V. A. 1986. Geologia e petrologia do macico monzodiorítico-monzonítico de Piracaia, São Paulo. M. Sc.thesis, Inst. Geociências, USP, 281 pp., São Paulo, SP.Brasil.

Janasi,V.A. 1992. Rochas sieníticas e mangerítico-charnockíticas neoproterozóicas da região entre Caldas e Campestre, MG: aspectos petrológicos. $\mathrm{PhD}$. thesis, Inst. Geociências, USP, 298 pp, São Paulo, SP, Brasil.

Janasi.V. A. 1993. Petrogenesis and tectonic setting of the neoproterozoic Capituva K-syenitic massif, SW Minas Gerais, Brazil. Rev. Bras. Geoc., 23 (2): 129-138.

Janasi, V. A. \& Ulbrich, H. G. J. 1987. Petrogenesis of the monzodioritic Piracaia Massif, State of São Paulo, southern Brazil: field and petrographic aspects. Rev. Bras. Geoc., 17 (4): 524-534.

Janasi.V. A \& Vlach, S. R. F. 1997. Sr and Nd isotope systematics of the Capituva and Pedra Branca syenitic massifs (SW Minas Gerais, Brazil): Petrogenesis and inferences on Neoproterozoic lithospheric mantle reservoirs. South-American Symp. On Isotope Geology (SSAGI), Ext. Abstracts, 143-146, Campos do Jordao, SP, Brasil.

Janasi.V. A.; Vlach, S. R. F.; Ulbrich, H. G. J. 1993. Enriched mantle contribution to the Itu Granitoid Belt, southeastern Brazil: evidences from K-rich diorites and syenites. An. Acad. Bras. Ci., 65 (supl. 1): 107-118, SBG, Rio de Janeiro, RJ, Brasil.

Janasi.V. A.; Haddad, R. C.; Vlach, S. R. F. 1997. Comments on the Sm-Nd isotope systematics of calc-alkaline granitoids from the Pinhal-Ipuiuna batholith (São Paulo and Minas Gerais, Brazil). South-American Symp. On Isotope Geology (SSAGI), Ext. Abstracts, 147-150, Campos do Jordao, SP, Brasil.

Kaul, P. F. T. 1997. O magmatismo na Serra do Mar e adjacencias (Sul do Brasil) no final do Neoproterozoico e seus condicionantes tectonicos. Ph.D. thesis, Inst. Geociências, USP, 293 pp., São Paulo, SP, Brasil.

Kinnaird, J. A.; Batchelor, R. A.; Whitley, J. E.; MacKenzie, A. B. 1985. Geochemistry, mineralization and hydrothermal alteration of the Nigerian high heat producing granites. In: High Heat Production (HHP) Granites, Hydrothermal Circulation and Ore Genesis. The Institution of Mining and Metallurgy, London, 169-195.
Kohler, U.C. 1990. Der Itu-Batholith (Nordteil): ein Rapakivi Granit, Bundestaat São Paulo, Brasilien. Geologische Kartierung, Petrographie, Geochemie. Versuch einer Interpretation. MS-thesis, Institut fOr Allgemeine und Angewandte Geologie, Ludwig Maximilian Universitat, Munchen, Germany, $81 \mathrm{pp}$

Machado, R. 1997. Litogeoquímica e tectónica dos granitóiodes Neoproterozóicos do cinturão Paraíba do Sul no Estado do Rio de Janeiro. PhD-thesis, Inst. Geociências, USP, 215 pp, São Paulo, SP, Brasil.

Machado, R. \& Endo, I. 1993. O Cinturão de cisalhamento Atlântico: um exemplo de tectônica transpressional neoproterozóica. Bol. Resumos $4^{\circ}$ Simpósio National de Estudos Tectônicos: 188-191, Belo Horizonte, MG, Brasil.

Martin, R.F. 1989. Metasomatic "ground preparation"and the origin of anorogenic granites. IN: Haapala, I. and Kähkönen, Y. (eds.) Symposium Precambrian Granitoids: Petrogenesis, Geochemistry, Metallogeny, Geological Survey of Finland, Special Paper 8, p. 87.

Martin, R. F. \& Bowden, P. 1981. Peraluminous granites produced by rock-fluid interaction in the Ririwai nonorogenic ring-complex, Nigeria: mineralogical evidence. Can. Mineral., 19: 65-82.

Muller, D.; Rock, N. M.; Groves, D. I. 1992. Geochemical discrimination between shoshonitic and potassic volcanic rocks in different tectonic settings: a pilot study. Mineral. Petrol., 46: 259-289.

Pascholati, E. M. 1990. Caracterização geofisica da Suite Intrusiva Itu, São Paulo. PhD-thesis, Inst. Astronomia e Geofisica, USP, São Paulo, SP, Brasil, 135 pp.

Pascholati, E. M.; Vlach, S. R. F. \& Amaral, G. 1987. Contribuição ao conhecimento da Suíte Intrusiva Itu, São Paulo. Atas $6^{\circ}$ Simp. Reg. Geol., 1: 47-62. Sociedade Brasileira de Geologia, Núcleo de São Paulo, Rio Claro, SP, Brasil.

Ribeiro, A.; Trouw, R. A. J.; Andreis, R. R.; Paciullo, F. V.P.; Machado, N. 1995. Evolução das bacias proterozóicas e o termo-tectonismo brasiliano na margem sul do cráton do São Francisco. Rev. Bras. Geoc., 25 (4): 235-248.

Rogers, J. J. W. \& Satterfield, M. E. 1994. Fluids of anorogenic granites: A preliminary assesment. Mineral. Petrol., 50: 157-171.

Rothmaier, R. 1994. Die Rapakavi-Intrusion Sguario, Campina do Veado und Rio Pirituba: Hybridgesteine und Magmenmischung im Bundestaat São Paulo, Brasilien. Geologische Kartierung, Petrographie, Geochemie, Zirkonmorphologie. MSc-thesis, Geologisch-Palaontologisches Institut, Eberhard-Karls Universitat, Tubingen, Germany, 95 pp.

Ruf, M. 1990. Der Itu-Komplex, ein Teil des Magmatismus im sudlichen Ribeira Mobile Belt, São Paulo / Brasilien. Geochemische und Petrographische Untersuchungen unter besonderer Beriicksichtigung akzessorischer Zirkone. MS-thesis, Institut fur Allgemeine und Angewandte Geologie, Ludwig Maximiliam Universitat, Munchen, Germany, 93 pp.

Sabderson, D. J. \& Marchini, W. R. D. 1984. Transpression. J. Struct .Geol., 6:449-459.

Schmidt-Thome, R. \& Weber-Diefenbach, K. 1987. Evidence for "frozen-in" magma mixing in Brasiliano calc-alkaline intrusions: The Santa Angelica pluton, southern Espírito Santo, Brazil. Rev. Bras. Geoc., 17 (4): 498-506.

Sengor, A. M. C. 1990. Plate tectonics and erogenic research after 25 years: a Tethyan perspective. Earth Sci. Rev., 27: 1-201.

Siga Jr., 0.1995. Domínios tectônicos do sudeste do Paraná e nordeste de Santa Catarina: geocronologia e evolução crustal. Ph.D. thesis, Inst. Geociências, USP, 212 pp, São Paulo, SP, Brasil.

Siga Jr., 0.; Basei, M. A.; Reis Neto, J. M. dos; Buba, R. M. 1994. Maciços graníticos da porção sudeste do Paraná e nordeste de Santa Catarina: geocronologia e implicações tectônicas. 38. Congr. Bras. Geol., Ext. Abstracts, 3, 400-401, SBG, Balneário Camboriú, SC, Brasil.

Siga Jr., 0.; Basei, M. A. S.; Reis Neto, J. M.; Harara, O. M.; Passarelli, C. R.; Prazeres, H.; Weber, W.; Machiavelli, A. 1997. Ages and tectonic setting of alkaline-peralkaline granitoids of Paraná and Santa Catarina States, southern Brazil. South-American Symp. On Isotope Geology (SSAGI), Ext. Abstracts, 301-303, Campos do Jordão, SP, Brasil.

Soave, L. A. \& Wernick, E. 1997. Brazilian granitoid dimension stones. II International Symposium on Granites and Associated Mineralization (II ISGAM), Extended Abstract, 304-305, Salvador, BA, Brasil.

Soares, P. C. \& Rostirolla, S. P. 1997. Tectônica de escape tardicolisional nos Cinturões Ribeira e Dom Feliciano. Bol. Resumos VI Simposio National de Estudos Tectonicos, 65-68, Pirenópolis, GO, Brasil.

Soares, P. C.; Fiori, A. P.; Carvalho, S. G. D. 1990. Tectonica colisional oblíqua entre o bloco Paraná e a margem sul do craton S. Francisco, no maciço Guaxupé. An. 36. Congr. Bras. Geol., 7: 63-79, SBG, Natal, RN, Brasil.

Soper, N. J. \& Hutton, D. H. W. -1984-Late Caledonian sinistral displacements in Britain: implications for a three-plate collision model. Tectonics: 3: 781-794.

Strachan, R. A.; Holdsworth, J. D.; Friederichsen, J. D.; Jepsen, H. F. 1992. Regional Caledonian structure within an oblique convergence zone, Dronning Louise Land, NEE Greenland. J. Geol. Soc., London, 149: 359-371.

Sylvester, P. J. 1989. Post-collisional alkaline granites. J. Geol., 97: 261-280.

Tassinari, C. C. G. 1988. As idades das rochas e dos eventos metamórficos da porção sudeste do Estado de São Paulo e sua evolução crustal. Pos-PhD-thesis. Inst. de Geociências, USP, 236 pp., São Paulo, SP, Brasil. 
Tassinari, C. C. G.; Kawashita, K.; Schmuss, R. V. \& Taylor, P. N. 1988. A idade das rochas e dos eventos metamórficos da Região SE do Estado de São Paulo. An. XXXV Congr. Bras. Geol, 6: 2840-2853. Sociedade Brasileira de Geologia, Betem, PA Brasil.

Teuppenhaym, J. P. 1994. Der spätpräkambrische Granit-Pegmatit-Komplex bei Perus und umliegende Granitkärper im Bundestaat São Paulo/SE Brasiliens. Müinchner Geol. Hefte - Reihe A (Allgemeine Geologic), 14, 360 pp., München, Germany.

Tikoff, B. \& Teyssier, C. 1994. Strain modeling of displacement-field partioning in transpressional orogens. Am. Ass. Petrol. Geol. Bull., 81: 1625-1640.

Topfner, C. 1996. Brasiliano -Granitoide in den Bundesstaaten São Paulo and Minas Gerais, Brasilien -Eine vergleichende Studie (Zircontypologie, $\mathrm{U}$-(Th) - $\mathrm{Pb}$ und $\mathrm{Rb}-\mathrm{Sr}$ Altersbestimmungen). Münchner Geol. Hefte-Reihe A (Allgemeine Geologie), 17, 258 pp., München, Germany.

Vauchez, A.; Tommasi, A.; Silva, M. E.; Trompette, R. 1992. Tectônica de escape na terminação de um craton: a Faixa Ribeira. Bol. Resumos Expandidos, 37. Congr. Bras. Geol., 2: 373-375, SBG, São Paulo, SP, Brasil.

Vlach, S. R. F. \& Cordani, U. G. 1986. A sistemática Rb/Sr em rochas granitóides: considerações interpretativas, limitações e exemplos brasileiros. Rev. Bras. Geoc., 16(1):38-53.

Wernick.E. 1983. Granites na região da Grande São Paulo. $4^{\circ}$ Simp. Reg. Geol., Excursion Guide, 21 pp., SBG (Núcleo São Paulo), São Paulo, SP,.Brasil.

Wernick, E. 1996. Geodynamic and magmatism during the Late Precambrian (Brasiliano Cycle) in SE Brazil reported by the pluriserial Socorro Complex (States of São Paul and Minas Gerais). Terra Nostra 8/96: 151-153. Schriften der Alfred Wegener Stiftung. $\quad 15$ Geowissenschaftliches Lateinamerika-Kolloquium (Zusammenfassung der Tagungsbeitrage), Hamburg.

Wernick, E. 1991 a. Idade de colocação do magmátismo Brasiliano no Estado de São Paulo e áreas adjacentes do Estado de Minas Gerais, SE Brazil. Bol. Resuntos, Vl Simpósio Nacional de Estudos Tectônicos, 104-106, SBG, Pirenópolis, GO, Brasil

Wernick, E. 1997b. Brasiliano granitoid magmatism, State of São Paulo and neighbourhood, SE Brazil: emplacement episodes. South-American Symposium on Isotope Geologi (SSAGI), Extended Abstracts, 330-331, Campos do Jordão, SP, Brasil.

Wernick, E. 1998a. O Sistema Magmático 590 do Cinturão Ribeira (Ciclo Brasiliano, Pré-Cambriano Superior). Actas II Congreso Uruguayo de Geologia: 300-305, Punta del Este, Uruguay.

Wernick, E. 1998b. Sistema Magmótico Pluriserial 590: caracterização e implicações geodinâmicas. An. 40. Congr. Bras. Geol.: 46, SBG, Belo Horizonte, MG, Brasil

Wernick, E. \& Ferreira, C. J. 1993. Estruturas, arquitetura e evolução do complexo granitóde Itaqui, SP. Geociências (UNESP): 12 (1): 89-109.

Wernick, E. \& Menezes, A. do C. 1997. Caracterização geoquímica de rochas cumuláticas na suíte alcalina potássica Piracaia, SP. Atas V Simp. Geol. Sudeste, 1: 112-114, SBG (núcleos SP/RJ-ES) \& ABGE (núcleo RJ), Penedo, Itatiaia, RJ, Brasil..

Wernick, E \& Menezes, A do C. 1998. The Late Precambrian K-alkaline magmatism in the Ribeira Fold Belt: a case study of the Piracaia magmatism, State of São Paulo, SE Brazil. Ore Geology Review (Special issue), in press.

Wernick, E. \& Teuppenhayn, J. P. 1999. Origin and evolution of the aluminous calc-alkaline serie based on the case study of the "Pirituba" magmatism, State of São Paulo, SE Brazil. Proceedings of the II ISGAM, Salvador, Brazil, 1997. An.Acad.Bras.CL, 71(1): 99-130.

Wernick, E. \& Topfner, C. 1997. Idades do magmátismo granitóide Brasiliano nos Estados de São Paulo e Minas Gerais: implicates na caracterização temporal da evolução do Cinturão Ribeira. Atas V Simp.Geol.Sudeste, 1: 159-161, SBG (núcleos SP/RJ-ES)/ABGE, Penedo, Itatiaia, RJ, Brasil.
Wernick, E.; Artur, A. C.; Ferreira, C. J. 1995. Evolução magmática em complexos granitóides associados a zonas de cisalhamento no Estado de São Paulo, Brasil. Geociências, (UNESP), 14 (1): 199-216.

Wernick, E.; Galembeck, T. .M. B. \& Massoni, F. 1998a. As séries álcali-cálcicas do Sistema Magmático Plurisserial 590 do Cinturão Ribeira (Ciclo Brasiliano). An. XL Congr. Bras. Geol, SBG, 498, Belo Horizonte, MG, Brasil.

Wernick, E.; Galembeck, T. .M. B. \& Massoni, F. 1999b. High-K rocks from the Pluriserial Ribeira Magmatic System-590, SE and S Brazil: II - The Alkali-Calcic Group. Submitted Rev. Bras. Geoc.

Wernick, E.; Godoy, A. M. \& Galembeck, T. .M. B. 1991. The São Francisco, Sorocaba and Itu rapakivi complexes (Late Precambrian, State of São Paulo, Brazil): geological, petrographic and chemical aspects. Symposium on Rapakivi and Related Rocks. In (I.Haapala and O.T.Ramfi, ed.): Abstract Volume, 61-62, Espoo, Finnland.

Wernick, E.; Godoy, A. M. \& Galembeck, T. .M. B. 1994. Fases magmáticas e aspectos quimícos dos complexos rapakivi Sorocaba, São Francisco e Itu, SP: um estudo comparative. Geociências, 13 (1): 175-183. Universidade Estadual Paulista, São Paulo, SP, Brasil.

Wernick, E.; Menezes, A. do; Topfner, C. 1997c. Os magmatismos alcalinos potássicos Piracaia (SP) e Pedra Branca (MG): um estudo comparative. Atas V Simp. Geol. Sudeste, 1: 172-174, SBG (núcleos SP/RJ-ES) \& ABGE (núcleo RJ), Penedo, Itatiaia, RJ, Brasil.

Wernick, E.; Menezes, A. do; Zacharias, A. A. 1998b. Rochas alcalinas do Sistema Magmático Plurisserial-590 do Cinturão Ribeira (Ciclo Brasiliano). An. XL Congr. Bras. Geol., SBG, 493, Belo Horizonte, MG, Brasil.

Wernick, E.; Menezes, A. do; Zacharias, A. A. 1999a. High-K rocks from the Pluriserial Ribeira Magmatic System-590: I - The Shoshonitic/Alkaline/Peralkaline Group. Submitted Rev. Bras. Geoc.

Wernick, E.; Fiori, A. P.; Bittencourt, J. S.; Choudhuri, A. 1981. A tectonica rígida do fim do Ciclo Brasiliano e sua implicafao na estruturação da borda sul e sudoeste do craton do São Francisco: tentativa de um modelo preliminar. An. Simposio sobre o Craton do São Francisco e suas Faixas Marginals, 164-168, SBG, Salvador, BA, Brasil.

Wernick, E.; Hermann, P. K.; Artur, A. C.; Ferreira, C. J.; Galembeck, T. .M. B.; Godoy, A. M. \& Andrade, F. R. D. de. 1993. Fases, impulses e ciclos magmáticos em complexos granitoides associados com falhas transcorrentes, SP. Rev. Bras. Geoc., $23(3): 248-259$.

Wernick, E.; Galembeck, T. M. B.; Godoy, A. M. Hermann, P. K. 1997a Geochemical variability of the Rapakivi Itu Province, State of São Paulo, SE Brazil. An. Acad. Bras. CL, 69 (3): 395-413, ABC, Rio de Janeiro, RJ, Brazil.

Wernick, E.; Artur, A. C.; Hermann, P. K.; Weber-Diefenbach, K.; Fahl, F. C. 1997b. O magmatismo Piracaia, SP (SE Brasil): aspectos composicionais e evolutivos. Rev. Bras. Geoc., 27 (1): 53-66, SBG, São Paulo, SP, Brasil.

Wiedemann, C. M. 1993. The evolution of the Paleozoic, late to post-collisional magmatic arc of the coastal mobile belt in the State of Espírito Santo, Eastern Brazil. An. Acad. Bras. Ci.,65(Supl. 1): 163-181.

Winters, A. A. M. 1981. A geologia do maciço sienítico da Pedra Branca, Caldas-MG. M. Sc. thesis, Inst. Geociencias, USP, 92 pp, São Paulo, SP, Brasil

Zielenski, M. 1993. Petrologie und Zirkontypologie der Granite van Itu und São Roque Staat São Paulo (Brasilien). MS-thesis, Mineralogisch-Petrographisches Institut und Museum, Christian-Albrecht Universitat, Kiel, Germany, 80 pp.

Manuscrito A-1043

Recebido em 01 de dezembro de 1998 Revisao aceita em OS de Janeiro de 1999 